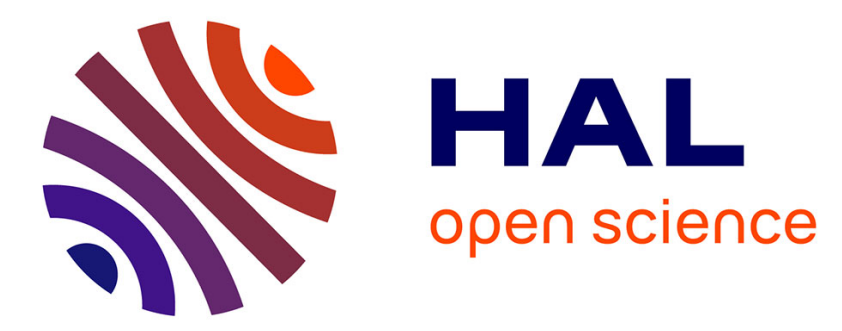

\title{
Numerical study of eddy generation in the western part of the Gulf of Lion
}

\author{
Ziyuan Hu, Anne Petrenko, Andrea M. Doglioli, I. Dekeyser
}

\section{To cite this version:}

Ziyuan Hu, Anne Petrenko, Andrea M. Doglioli, I. Dekeyser. Numerical study of eddy generation in the western part of the Gulf of Lion. Journal of Geophysical Research. Oceans, 2011, 116, pp.C12030. 10.1029/2011JC007074. hal-00691185

\section{HAL Id: hal-00691185 https://hal.science/hal-00691185}

Submitted on 5 Jan 2022

HAL is a multi-disciplinary open access archive for the deposit and dissemination of scientific research documents, whether they are published or not. The documents may come from teaching and research institutions in France or abroad, or from public or private research centers.
L'archive ouverte pluridisciplinaire HAL, est destinée au dépôt et à la diffusion de documents scientifiques de niveau recherche, publiés ou non, émanant des établissements d'enseignement et de recherche français ou étrangers, des laboratoires publics ou privés.

$$
\text { Copyright }
$$




\title{
Numerical study of eddy generation in the western part of the Gulf of Lion
}

\author{
Z. Y. Hu, ${ }^{1,2}$ A. A. Petrenko, ${ }^{1}$ A. M. Doglioli, ${ }^{1}$ and I. Dekeyser ${ }^{1}$ \\ Received 4 March 2011; revised 8 October 2011; accepted 10 October 2011; published 21 December 2011.
}

[1] A realistic numerical model is used to investigate the generation process of anticyclonic eddies located in the western part of the Gulf of Lion. During 8 years of simulations from 2001 to 2008, 8 anticyclonic coastal eddies with a life duration longer than 15 days have been observed in the study area between July and early October. The formation process of eddies is linked to the wind stress curl in the area. Nonetheless a simpler criteria can be used examining the changes in the wind amplitude at a key coastal station. The influences of this factor and of the stratification conditions over the study area are investigated, alone or combined, regarding the eddy's formation process. Our results show that these eddies need two conditions to be generated: a persistent and strong northwest wind and a strong stratification. The Ekman transport associated to such a wind and the coastline shape characterized by the presence of capes can create a pressure gradient generating an anticyclonic circulation. At the same time, a strong stratification condition allows a better transfer of wind-induced potential energy to eddy kinetic energy. Persistent wind bursts are also required to sustain the eddy in size and intensity. The present work contributes to a better understanding of the hydrodynamics of the Gulf of Lion.

Citation: Hu, Z. Y., A. A. Petrenko, A. M. Doglioli, and I. Dekeyser (2011), Numerical study of eddy generation in the western part of the Gulf of Lion, J. Geophys. Res., 116, C12030, doi:10.1029/2011JC007074.

\section{Introduction}

[2] The Gulf of Lion (hereafter GoL) is a large continental shelf located in the northwestern Mediterranean Sea (Figure 1). As described by Millot [1990], the hydrodynamics of the GoL are complex and highly variable, influenced by three main forcings coexisting in this area: i) strong continental winds: Tramontane (northwesterly, hereafter NW wind) and Mistral (northerly). The up- and downwelling phenomena generated by the wind along the coast are wellknown [Millot, 1979, 1982; Hua and Thomasset, 1983]; ii) a mesoscale quasi-geostrophic current, the Northern Current (NC) [Millot, 1991], flowing along the GoL continental slope from the Ligurian Sea to the Catalan Sea (Figure 1). The hydrodynamics of the NC have been well investigated by previous studies [Millot, 1990, 1999; Albérola et al., 1995; Sammari et al., 1995; Petrenko, 2003; Flexas et al., 2002; Echevin et al., 2003]; iii) fresh water inputs from the Rhône river, bringing nutrients that enhance primary productivity on the shelf [e.g., Minas and Minas, 1989; Ludwig et al., 2009]. The river plume extends offshore toward the southwest part of the GoL under certain meteorological conditions [Estournel et al., 1997].

\footnotetext{
${ }^{1}$ Laboratoire d'Océanographie Physique et Biogéochimique, UMR6535, Aix-Marseille Université, CNRS, IRD, OSU/Centre d'Océanologie de Marseille, Marseille, France.

${ }^{2}$ Now at JiaoZhou Bay Marine Ecosystem Research Station, Institute of Oceanology, Chinese Academy of Sciences, Qingdao, China.

Copyright 2011 by the American Geophysical Union. 0148-0227/11/2011JC007074
}

[3] A potential mesoscale anticyclonic circulation in the western part of the GoL has been first identified by Millot $[1979,1982]$ in the currents and SST images. In the latter, it was partly associated to a tongue of cold water upwelled south of Cape d'Agde. Its signature can also be observed in SeaWiFs chlorophyll maps with a high chlorophyll $a$ plume on its northern edge circling around the eddy $[\mathrm{Hu}$ et al., 2009]. During the oceanographic cruise Latex $08, \mathrm{Hu}$ et al. [2011] also observed an anticyclonic eddy in the western part of the GoL and suggested that the radius of the eddy is estimated to be $15-20 \mathrm{~km}$. The maximum life duration of these anticyclonic eddies is estimated to be up to about 2 months [Hu et al., 2009, 2011]. The spatial and temporal scales of these coastal eddies are distinct from those of the large eddies observed in the open ocean like the Gulf Stream rings and the Agulhas rings. They are also smaller than those of the eddies observed in the Mediterranean sub-basin, such as the Algerian eddies which can have lifetimes up to $\sim 3$ years and can reach diameters larger than $\sim 250 \mathrm{~km}$ [Millot et al., 1990; Ruiz et al., 2002]. However, eddies are among the physical processes that can have an important role over the continental shelf edge listed by Huthnance [1995]. Indeed, these coastal eddies can be considered as a link between the coastal water and the open sea and could have an important influence on the coast-offshore transport of nutrients and phytoplankton, as well as heat and energy.

[4] Hence, it is important to understand the physical dynamics of these eddies and, in particular, their generation process. Various dynamical processes can contribute to eddy generation [McWilliams, 1985]. For instance, current instabilities are important mechanisms for eddies of the Gulf 


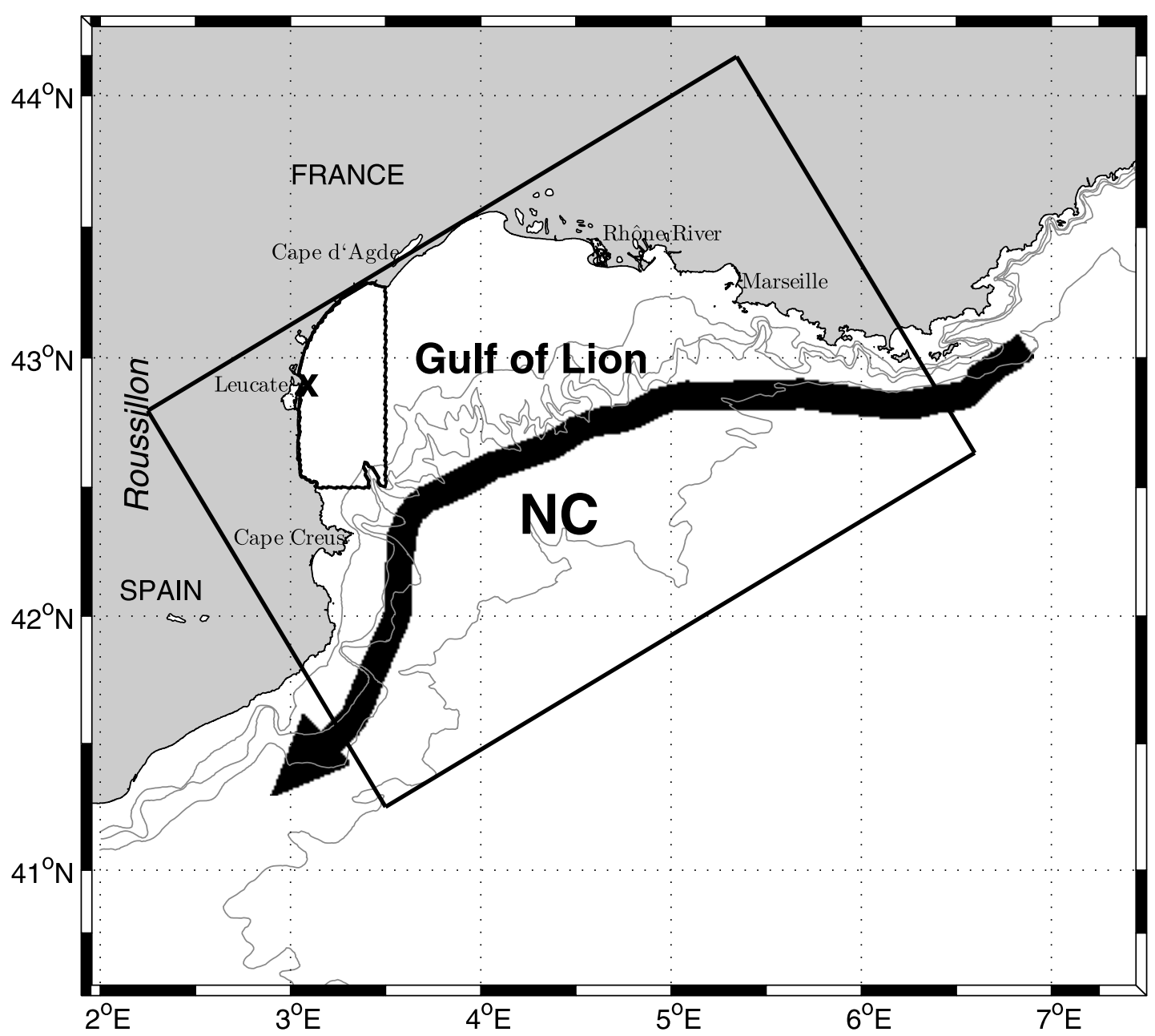

Figure 1. Map of the Gulf of Lion. The rectangle represents the model domain. The contour indicates the study area where eddies are often observed. The big cross indicates the location of meteorological station at Leucate. Isobaths at 100, 200, 500 and $2000 \mathrm{~m}$ are plotted with gray lines.

Stream [e.g., Robinson et al., 1988], or in the Gulf of Mexico [e.g., Hurlburt and Thompson, 1980]. The topographical influence is an important contributor to the Meddies (eddies of Mediterranean Water) formed near Cape Saint Vincent [Pichevin and Nof, 1996] and, in general, to all the eddies formed around capes or around headlands [e.g., Signell and Geyer, 1991; Doglioli et al., 2004; Magaldi et al., 2010]. The eddies in the lee of the Hawaiian islands are formed as a result of combined wind-forcing, topography and instabilities associated with current flow [Lumpkin, 1998; Chavanne et al., 2002; Kersalé et al., 2011]. In the Northwestern Mediterranean basin, Pascual et al. [2002] suggested that an eddy observed in the Balearic Sea is created by the wind stress curl. Coastal anticyclonic eddies observed in the eastern part of the GoL [Allou et al., 2010] and in the Catalan Sea [Rubio et al., 2005; Rubio et al., 2009a] are created by a separating branch of the NC due to the topography. Schaeffer [2010] also showed that the generation mechanism of anticyclonic eddies in the eastern part of the GoL are related to the local wind conditions. In our study area, Millot $[1979$, 1982] suggested that anticyclonic circulation may arise in the surface layer in the western part of the GoL to compensate the offshore departure of coastal waters following an upwelling phenomena. Estournel et al. [2003] and Petrenko et al. [2008] also showed that the wind stress curl over the GoL can create an anticyclonic eddy circulation over the shelf of the gulf by using idealized simulations. However, the precise generation mechanism of the eddy located in the western part of the GoL is still not clear. Hence, starting from the hypothesis of Millot [1979, 1982], we investigate the generation process of anticyclonic eddies. The present work is carried out within the framework of the LAgrangian Transport EXperiment (LATEX) projet (2008-2011) initiated to study the role of mesoscale eddies on shelf-offshore exchanges in the GoL. The objectives of the paper is to characterize shallow coastal eddies in the western part of the Gulf of Lion and to explain their generation process.

[5] The paper is organized as follows: section 2 describes the numerical approach, the wind-forcing analysis and eddy identification technique; section 3 presents the comparison between the numerical results and observations; section 4 investigates eddy formation process depending on the various wind-forcing and stratification conditions; the results 
Table 1. Table of Percentage of Northwesterly Events and the Corresponding Maximum and Average Wind Amplitude for the Period May-October

\begin{tabular}{lccccccccc}
\hline \multicolumn{1}{c}{ Year } & 2001 & 2002 & 2003 & 2004 & 2005 & 2006 & 2007 & 2008 & 8 Years Averaged \\
\hline Percentage of northwesterly & 55 & 59 & 50 & 53 & 53 & 47 & 62 \\
Max. northwesterly amplitude $\left(\mathrm{ms}^{-1}\right)$ & 16 & 20 & 19 & 17 & 19 & 17 & 19 & 18 & 54 \\
Avg. northwesterly amplitude $\left(\mathrm{ms}^{-1}\right)$ & 9 & 10 & 9 & 9 & 9 & 9 & 10 & 9 & 9 \\
\hline
\end{tabular}

are discussed in section 5 and the summary and conclusions are presented in section 6 .

\section{Material and Method}

\subsection{Numerical Modeling}

[6] For the present study, we use Symphonie, a 3-D primitive equation model, with a free surface, hybrid sigma coordinates, based on Boussinesq and hydrostatic approximations [Marsaleix et al., 2006, 2008].

[7] Symphonie has already been used in the area, for example to study the wind-induced circulation in the GoL [Auclair et al., 2003; Estournel et al., 2003; Petrenko et al., 2005, 2008], dense-water formation and/or cascading phenomena over the continental shelf [Dufau-Julliand et al., 2004; Ulses et al., 2008a, 2008b] and deep convection in the northwestern Mediterranean Sea [Herrmann and Somot, 2008; Herrmann et al., 2008]. A C-grid is used for spatial discretization [Arakawa and Suarez, 1982]. The secondorder closure scheme of Gaspar et al. [1990] is used to estimate vertical turbulence. Hu et al. [2009] developed and validated an upwind-type advection-diffusion scheme to improve the ability of the model to reproduce coastal mesoscale eddies. In the present application, the model domain extends throughout the whole GoL with a horizontal resolution of $1 \mathrm{~km}$ and $40 \sigma$-hybrid vertical levels (Figure 1). Surface atmospheric forcings are provided by the meteorological model Aladin of Météo-France with high spatial $\left(0.1^{\circ} \times 0.1^{\circ}\right)$ and temporal $(3 \mathrm{~h})$ resolutions. Initial and open boundary conditions are provided by the Mediterranean Forecasting System (MFS) general circulation model [Pinardi et al., 2003] with a resolution of $1 / 8^{\circ}$. The original forcing data are bilinearly interpolated in the Symphonie model grid, and linearly interpolated in time. Daily fluxes of fresh water from major rivers (Rhône, Hérault, Aude and Orb), are provided by the Compagnie Nationale du Rhône. Based on available data, we have simulated 8 years from January 2001 to December 2008. The daily outputs of current components, salinity, temperature and density are averaged over 24 hours of simulation, filtering diurnal and/or inertial oscillation (frequency is of 17.5 hours in the GoL corresponding to latitudes around $43^{\circ} \mathrm{N}$ ).

\subsection{Wind-Forcing Analysis}

[8] In order to study the generation process in response to changes in wind-forcings, we use the meteorological wind data used in our numerical simulations. Measured meteorological data are available at terrestrial stations around the GoL, among other at Leucate (Figure 1). We have compared the Aladin wind with the available measurements and have found a good agreement. In sake of conciseness we do not show this comparison. For this study, to illustrate the wind variability in the western part of the GoL, we have decided to use the Aladin model data at the grid point near the position of the meteorological Leucate station. Indeed, this location represents quite well the changes in the wind-forcing in the western part of the GoL, because it is systematically in the path of the NW wind whether it extends spatially or exhibits a strong wind stress curl. As shown afterwards, this method works well with this easy-to-compute criteria on the wind amplitude at Leucate. Hence this criteria was kept, in preference to other more complicated calculations on wind stress, in order to potentially be used in real-time at sea operations or in an operational system based on the wind measurements of the Leucate meteorological station. In the following we consider that the wind is a 'strong NW wind event' when its amplitude is larger than (or equal to) $8 \mathrm{~m} \cdot \mathrm{s}^{-1}$ and its direction between $270^{\circ}$ and $360^{\circ}$.

[9] Moreover a strong NW wind event persisting more than $75 \%$ of the last 3 days is defined as a 'persistent' strong NW wind.

[10] The percentage of the northwesterly, its presence, its maximum and average amplitude from May 1 till October 31 are computed for the 8 years of simulations in order to quantitatively estimate the wind-forcing (Table 1). 2002 and 2007 are two years during which the NW wind is particularly strong and persistent. These cases will be referred to -in the Discussion- as extremely strong persistent northwesterly events.

\subsection{Eddy Identification and Tracking}

[11] A wavelet signal analysis is used on the modeled horizontal relative vorticity to identify and follow coherent eddy structures in the numerical simulations (WATERS utility program [Doglioli et al., 2007]). This technique of signal decomposition in orthogonal wave packets provides both spatial and frequency information and has been largely used to detect coherent structures in spatial fields. We adjusted the number of spectral components associated with the eddies in order to filter out patterns of incoherent structures such as filaments. A group of grid points and a center are associated to each eddy. Eddy areas may therefore be computed as the sum of gridcell areas. Backward (forward) tracking finds the 'birth'('death') of the eddy. Hence we can deduce the life duration of the eddy. More details about the wavelet analysis and WATERS utility program are given by Doglioli et al. [2007]. More recently, WATERS has been used by Dencausse et al. [2010] to study the routes of Agulhas rings and by Rubio et al. [2009b] to investigate mesoscale activity in the Benguela upwelling system.

[12] In the present work, analysis is performed at $20-\mathrm{m}$ depth because, during the stratified season, it is about half the mixed layer depth over which the eddies extend.

[13] We performed the wavelet analysis on the 8 years of simulated horizontal relative vorticity field in order to identify all anticyclonic eddies present in the western part of the 
(a)

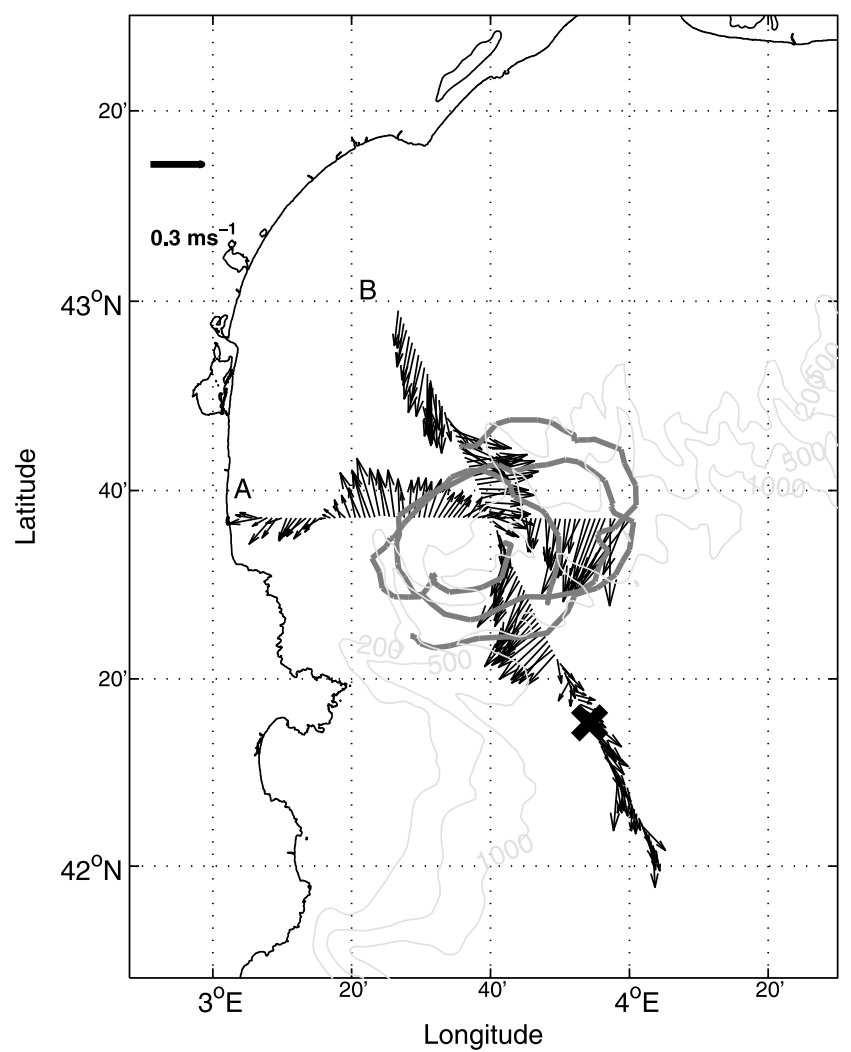

(b)

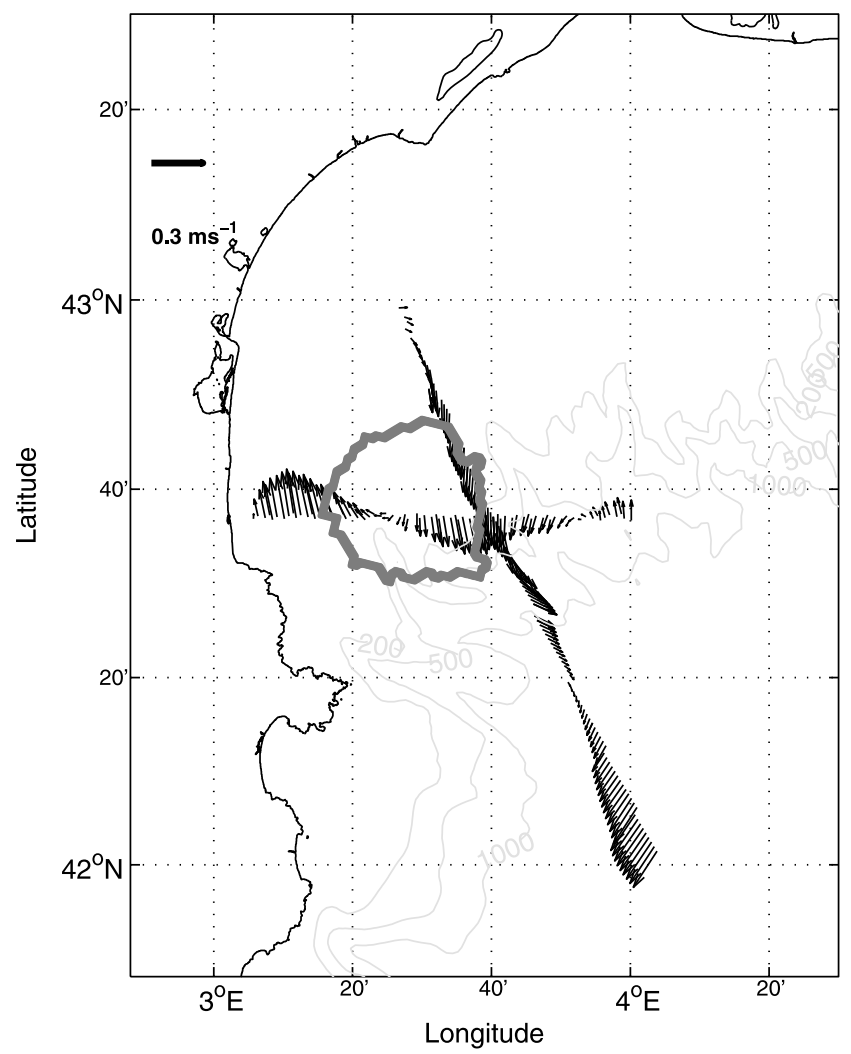

Figure 2. Comparison of the horizontal current field $\left(\mathrm{ms}^{-1}\right.$ ) at $15 \mathrm{~m}$ depth. (a) ADCP measured current along transect A on Sept. 1, and along transect B on Sept. 5, 2008. Dark gray contours represent the trajectories of two drifters from Sept. 5 to Sept. 11; the thick cross indicates XBT station. (b) Simulated current averaged from Sept. 1 00:00 to Sept. 2 00:00 along transect A and from Sept. 5 00:00 to Sept. 6 00:00 along transect B. Dark gray contour represents the eddy identification issued from the wavelet analysis on Sept. 10.

GoL and to track their life duration. The backward tracking in time of an identified eddy till its 'birth' helps us investigate its formation.

\section{Validation of the Modeling}

[14] The capability of the Symphonie model to reproduce the mesoscale circulation over the shelf in the GoL has been demonstrated by previous studies [Estournel et al., 2003; Petrenko et al., 2005, 2008; Dufau-Julliand et al., 2004; Ulses et al., 2008a]. Here we present a short comparison between the ADCP, drifters and XBT data gathered during the experiment Latex08 and the simulation carried out on the year 2008. The Latex08 cruise took place from September 1 to 5, 2008 on board the RV Téthys II. More details on the experiment are given by $\mathrm{Hu}$ et al. [2011].

[15] The ADCP data measured at $15 \mathrm{~m}$ depth along transect A (B) on Sept. 1 (Sept. 5) and the trajectories of the drifters from Sept. 5 to 11 are shown in Figure 2a. The northward (western part) and the southward (eastern part) currents along transect $\mathrm{A}$, the eastward (northern part) and the westward (southern part) currents along transect B reveal a continuous rotational clockwise circulation associated with an anticyclonic eddy. The drifters' trajectories illustrate its elliptic shape. The corresponding simulated currents along transect $\mathrm{A}$ and $\mathrm{B}$ are shown in Figure 2b. The observed anticyclonic eddy is reproduced by the model results as identified by the dark gray contour issued from the wavelet analysis on Sept. 10 and by the modeled clockwise circulation along transect A. The major pattern of the eddy agrees with the observations, although the intensity and the horizontal dimension of the simulated eddy are slightly less than those of the observed one. The simulated eddy is more northwest and onshore in position than the measured one. The observed clockwise rotation along transect $\mathrm{B}$ is not reproduced since transect B, crossing diagonally the observed eddy, is on the outer edge of the simulated one. In the southern extremity of transect B, the modeled southwestward current with an intensity comparable to the eddy's one suggests the presence of the NC, not present in the observations. Since the sea state during the cruise did not allow the use of the CTD we had on board, no comparison of hydrological fields could be applied with the simulation. Nevertheless, we have one temperature profile measured by an XBT (marked as black cross in Figure 2a) that we compare with the model results in Figure 3. At the surface, the discrepancy between the observed and modeled temperature is less than $0.2^{\circ} \mathrm{C}$. The observed thermocline starts at $35 \mathrm{~m}$ depth, while the modeled one starts about 5-10 $\mathrm{m}$ deeper. Below the thermocline till $200 \mathrm{~m}$ depth, the important gradient between the modeled temperature and the observed one is related to the presence of the NC [Petrenko et al., 2005] at the XBT position in the 


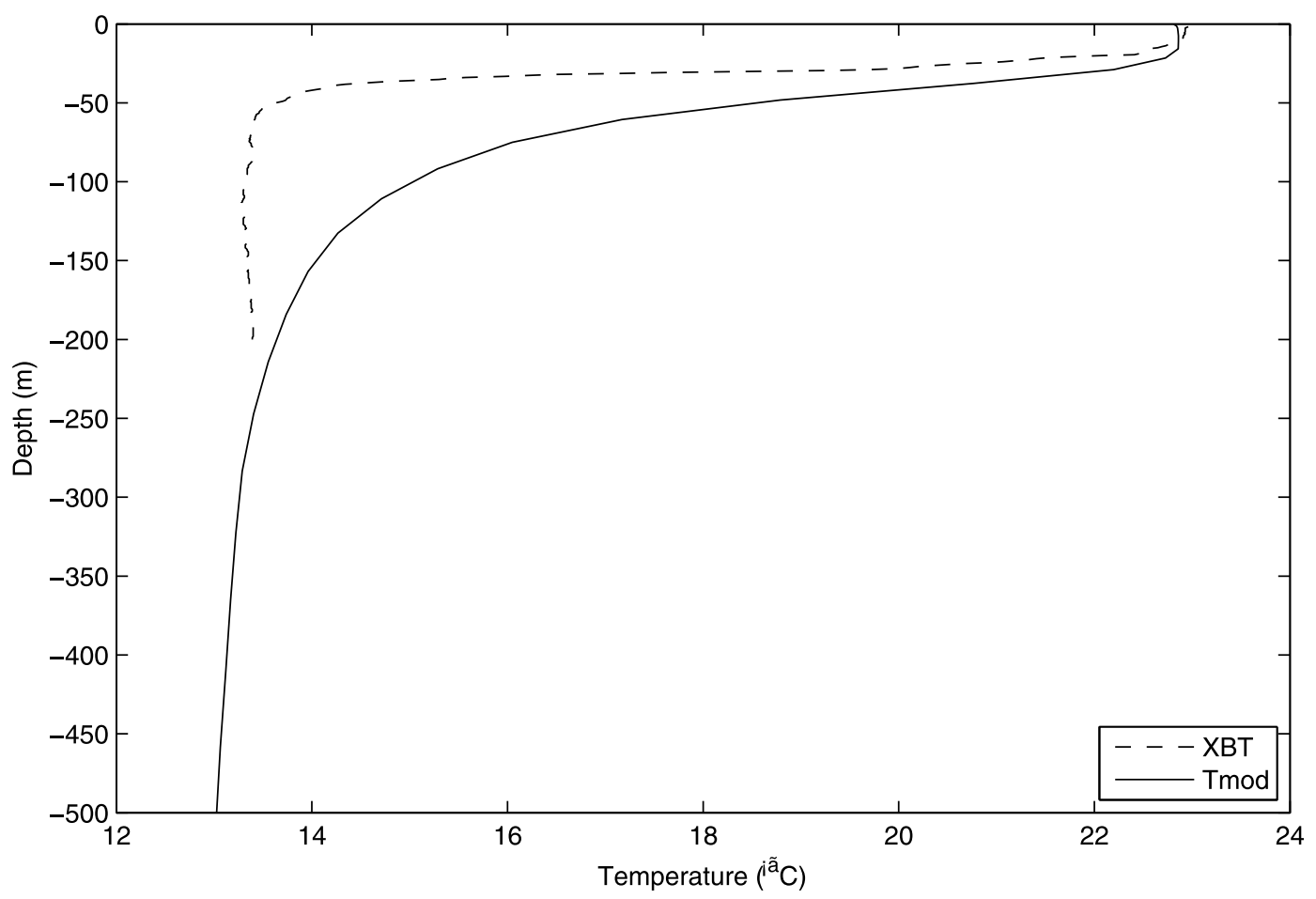

Figure 3. Vertical profile of temperature $\left({ }^{\circ} \mathrm{C}\right)$ simulated (solid line) and measured (dashed line) by XBT at cross location in Figure 2.

model results as shown by the ADCP data in Figure $2 b$. Although the measured XBT profile stops at $200 \mathrm{~m}$ depth, temperature has already stabilized at the temperature found at $250 \mathrm{~m}$ in the simulation. This temperature is close to $13.4^{\circ} \mathrm{C}$, the typical temperature of the Modified Atlantic Water (MAW) in this area [Albérola and Millot, 2003].

[16] One should note that the 24 hours daily averaged model outputs are not expected to reproduce the high variability of the circulation due to the wind. The goal of the present simulation is not to reproduce exactly the observed anticyclonic eddy but to reproduce most of the mesoscale dynamic processes in order to help us understand the eddies' generation mechanism. Previous simulation by $\mathrm{Hu}$ et al. [2009], with a model configuration identical to the present one, was carried out for the year 2001. It presents a good reproduction of realistic anticyclonic eddies in the GoL. The present simulation is run with the same configuration over 8 years, from 2001 to 2008 . Combined satellite observations over 8 years of simulation (not shown) and field observations in 2008 show that the model is able to reproduce the mesoscale eddies in the western part of the GoL over the whole simulated period. Hence it can serve as a tool to investigate eddy's generation process.

\section{Results}

[17] We examined the 8 years of simulated horizontal relative vorticity field and found that, in the western part of the GoL, anticyclonic features can be observed all year around.

[18] However, the anticyclonic features formed during winter and spring time are weak in intensity and smaller in size than the internal Rossby radius which is suggested to be
$15 \mathrm{~km}$ in this region [Grilli and Pinardi, 1998]. Generally lasting only 2-3 days, they do not consist of closed loops and hence are not considered as coherent eddy structures. In contrast, coherent and strong anticyclonic eddy structures are observed in our numerical simulations between May and October. These anticyclonic eddies generally consist of warm, less salty buoyant water with a positive sea-surface height anomaly (SSHA) comparing to the ambient waters. The features of these modeled eddies are in agreement with previous observations [Millot, 1979; Hu et al., 2011].

[19] The application of the wavelet analysis on all simulated coherent eddies in the simulations shows that these mesoscale anticyclonic eddies are about $20 \mathrm{~km}$ in diameter during their developing phase. Their horizontal dimension increases with time to be about $80 \mathrm{~km}$ when they get fully developed. Tracking analysis of these eddies shows that their life durations vary from several days to a couple of months.

[20] In the present work, we define as 'long-life' eddies the anticyclonic eddies which last at least 15 days, in opposition to the other ones that we call 'short-life' eddies.

[21] 'Long-life' is defined relatively to 'short-life' for the eddy structures in such a coastal study area, and hence can not be compared to the lifetimes of the open ocean eddies as, for example, the Agulhas Rings or the Algerian basin anticyclones. Regarding the actual conventions to separate submeso- and meso-scale [Thomas et al., 2008], our short-life eddies belong probably to the first category and the long-life ones to the second one.

[22] In the 8 years of simulations, 8 long-life anticyclonic eddies have been observed (Table 2). These long-life eddies occur during a three-month period, between July and early October. The convention to name them is: A $i_{-}$year; where $i$ 
Table 2. Information on the Long-Life Anticyclonic Eddies Present in the 2001-2008 Modeling of the Circulation in the Western Part of the GoL

\begin{tabular}{cccccc}
\hline Year & $\begin{array}{c}\text { Number } \\
\text { of Eddies }\end{array}$ & A1 & $\begin{array}{c}\text { Lifetime } \\
\text { (days) }\end{array}$ & A2 & $\begin{array}{c}\text { Lifetime } \\
\text { (days) }\end{array}$ \\
\hline 2001 & 1 & $23 / 07 \rightarrow 06 / 10$ & 76 & - & - \\
2002 & 1 & $07 / 07 \rightarrow 13 / 08$ & 38 & - & - \\
2003 & 2 & $07 / 07 \rightarrow 18 / 08$ & 43 & $12 / 09 \rightarrow 7 / 10$ & 26 \\
2004 & 0 & - & - & - & - \\
2005 & 2 & $10 / 07 \rightarrow 04 / 09$ & 57 & $20 / 09 \rightarrow 04 / 10$ & 15 \\
2006 & 1 & $04 / 08 \rightarrow 31 / 08$ & 28 & - & - \\
2007 & 0 & - & - & - & - \\
2008 & 1 & $15 / 07 \rightarrow 26 / 09$ & 72 & - & - \\
\hline
\end{tabular}

is the order of apparition during the July to October period of the year mentioned after the underscore. The first or the unique eddy generally appears in July (in the following indicated with A1 followed by the year, e.g. A1_2001), as it occurs 5 years out of the 6 during which eddies are present (2001, 2002, 2003, 2005 and 2008). The life durations of these first eddies range from 38 to 76 days, except for the 2006 eddy, which starts at the beginning of August and disappears at the end of that month lasting only 28 days. In 2003 and 2005, two long-life eddies have been detected successively during the three-month period. Both second eddies (indicated as A2 followed by the year) begin around midSeptember and disappear early October lasting 15 days in 2005 and 26 days in 2003 . Hence they generally last a shorter time than their July counterparts. Over the 8 years of simulations, we observe long-life eddies 5 times in July, 6 times in August, 5 times in September and 3 times in early October. No long-life eddy was detected in 2004 and in 2007. In summary, the period when a long-life anticyclonic eddy is more likely to be encountered in the western part of the GoL extends from July to early October with the highest probability in August.

[23] We present in Figure 4 an example of an anticyclonic eddy formed in the western part of the GoL nearly each year. These coastal eddies are rarely round in shape and have generally an elliptic form with a zonal major axis along the western coast (Figure 4).

[24] The horizontal dimension of the modeled eddy seems to be limited by the curvature of the western coastline. The irregular contour edge like the small 'tail' in the south edge of the eddy A1_2001 (Figure 4a) suggests the interaction of the eddy with the NC or surrounding currents. Eddy A1_2002 (Figure 4b) is smaller than the other eddies and is close to the coast. Eddy A2_2003 (Figure 4d) and eddy A2_2005 (Figure 4f) are located more offshore than the others. These eddies are all generated in the same area near the Roussillon coast at around $43^{\circ} \mathrm{N}, 3^{\circ} 15^{\prime} \mathrm{E}$. The diameter
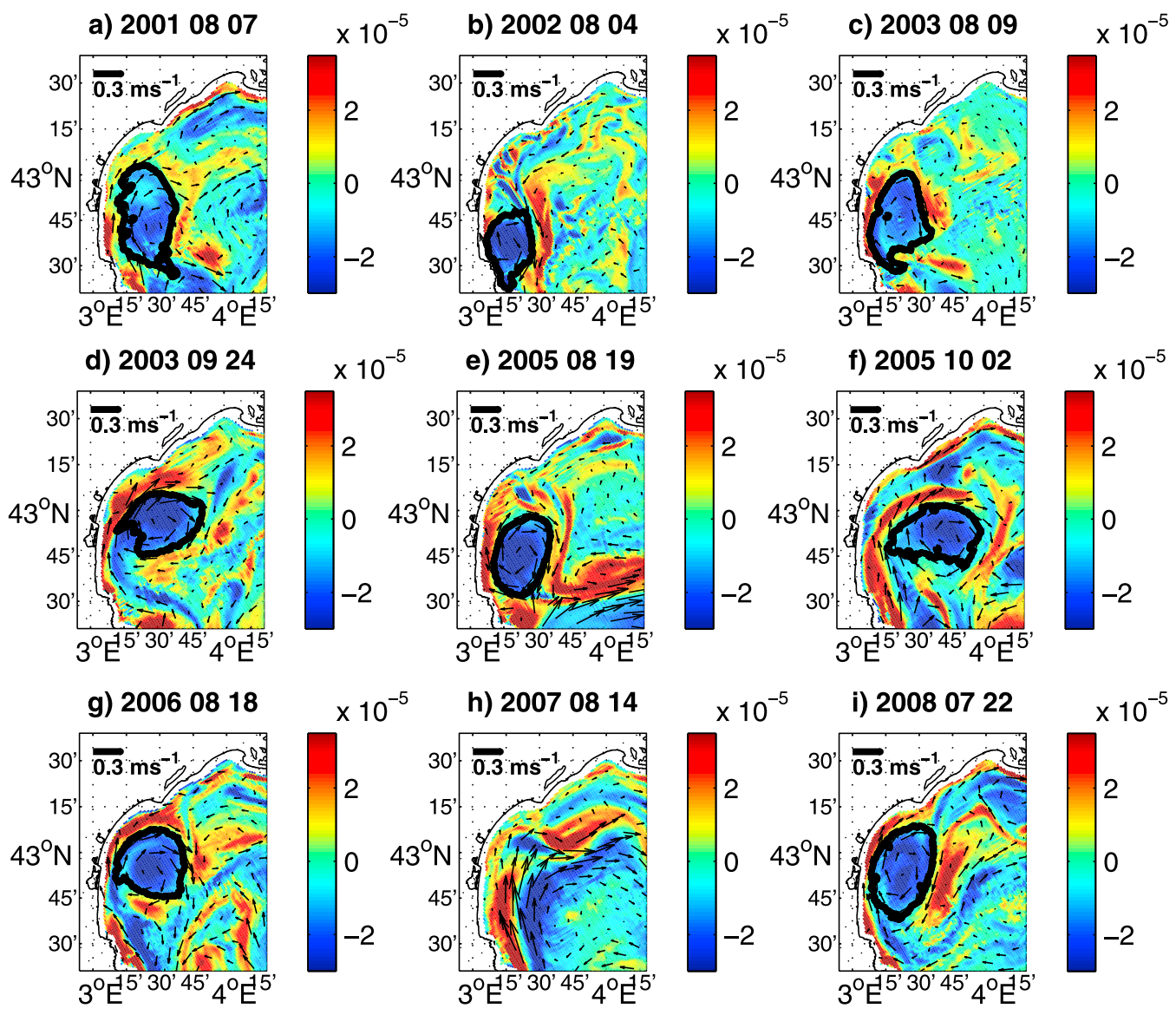

Figure 4. Snapshot of the modeled relative vorticity $\left[\mathrm{s}^{-1}\right]$ and current velocity at $20 \mathrm{~m}$ depth. The black contours issued from the wavelet analysis show the 8 long-life anticyclonic eddies once they are well-developed: (a) A1_2001, (b) A1_2002, (c) A1_2003, (d) A2_2003, (e) A1_2005, (f) A2_2005, (g) A1_2006, and (i) A1_2008. (h) The circulation over the western part of the shelf. 
a) 20050628

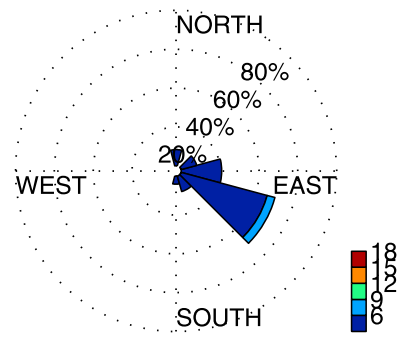

e)

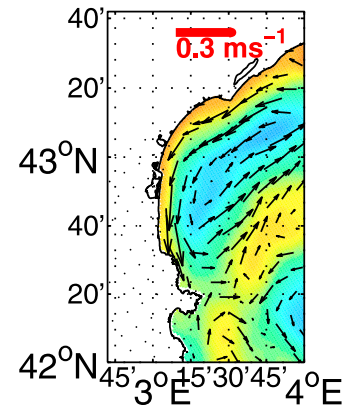

i)

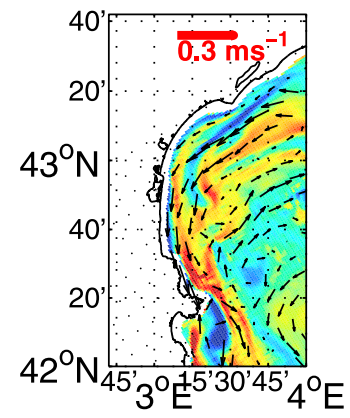

b) 20050702

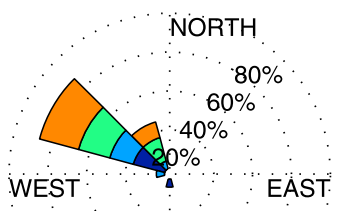

C) 20050706

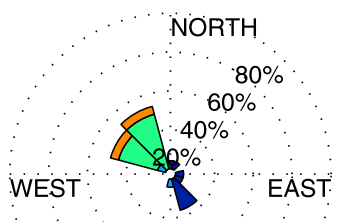

d) 20050710

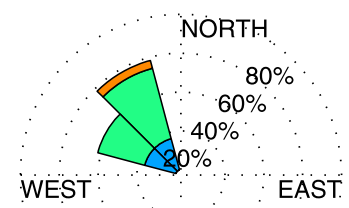

SOUTH

f)

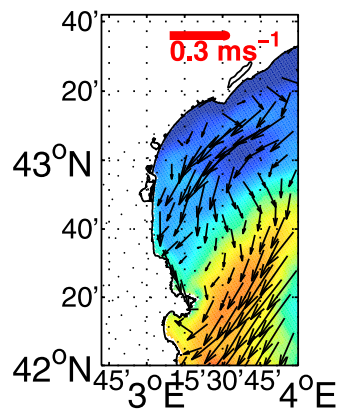

j)

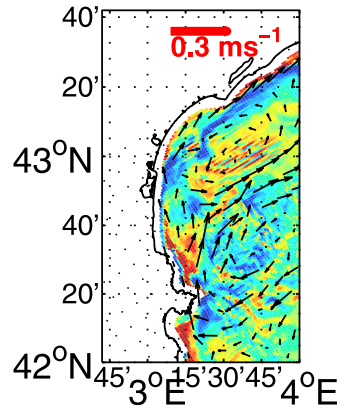

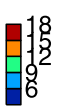

g)

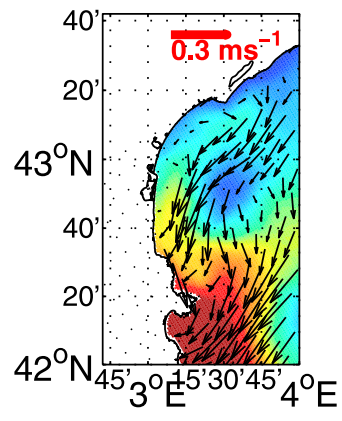

k)

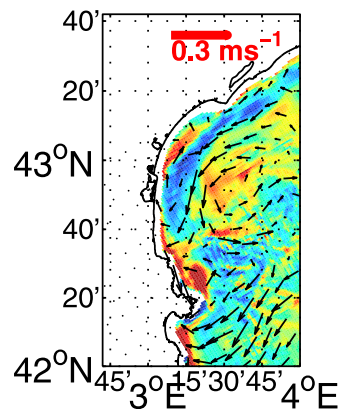

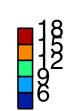

WEST $\because$ EAST

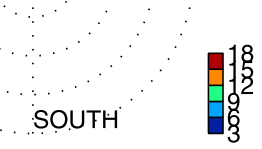

h)
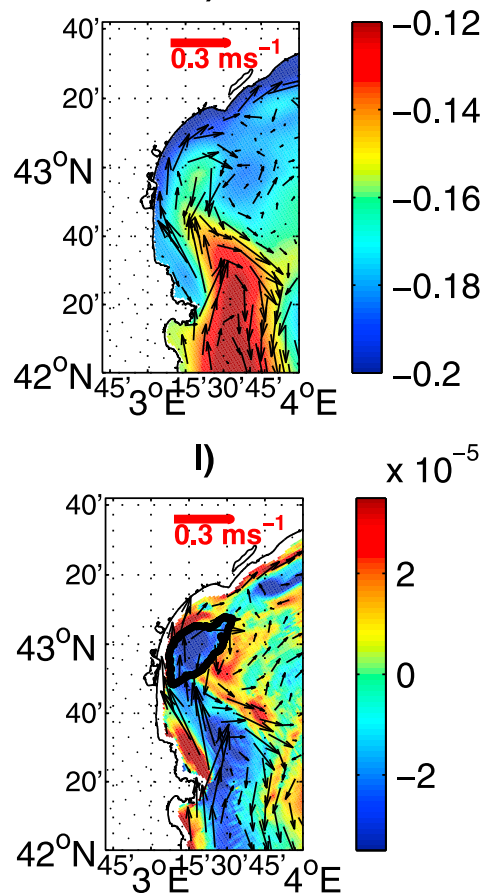

Figure 5. Time sequences of the generation process of the eddy $\mathrm{A}_{2} 005$ with 4 days of interval. Wind rose representation (intensity and frequency) at station Leucate on (a) 2005/06/26 to 28 , (b) 2005/06/30 to 07/02, (c) 2005/07/04 to 06, and (d) 2005/07/08 to 10, with colors representing wind intensity. Sea surface height and current velocity field at $5 \mathrm{~m}$ depth on (e) 2005/06/28, (f) 2005/07/02, (g) 2005/07/06, and (h) 2005/07/10. (i-1) Relative vorticity $\left(s^{-1}\right)$ computed at $20 \mathrm{~m}$ depth and current velocity fields corresponding to the same depth at the same dates as Figures $5 \mathrm{e}-5 \mathrm{~h}$. Black contour in Figure 51 shows the eddy identification issued from the wavelet analysis.

(elliptical diameter defined as the mean of the minor and major axes) of the eddies ranges from 10-20 km when they are newborn to $50-80 \mathrm{~km}$ when they are well-developed. After their generation, the eddies have slight meridional or offshore displacement to end up where they are shown on Figure 4. The NC located at their south-southeast edge (Figure 1), combined with the presence of Cape Creus, plays the role of a barrier and constrains the eddies within the western part of the GoL.

[25] No long-life eddies have been detected in 2004 and 2007. However, the circulations over the shelf during these two years are quite different. In 2004, only short-life anticyclonic features occur.

[26] In 2007, a large northeastward countercurrent (in the sense of Petrenko et al. [2008]), but not a closed anticyclonic eddy, occupies the whole west part of the GoL from late May till late October (Figure 4h). The south-east edge of this circulation consists of the NC along the continental slope.

\subsection{Influence of Wind-Forcing}

[27] It was demonstrated in previous studies [Millot, 1979, 1982; Estournel et al., 2003; Petrenko et al., 2008] that the coastal eddies/circulations in the GoL are strongly dependant on the wind events of this region.

[28] When the NW wind occurs, its stress curl is favorable to an anticyclonic vorticity in the western part of the GoL. Since the NW wind is quite frequent in this area over the whole year, in order to investigate the eddy generation in response to wind-forcing, we have tried to find a situation where a strong burst of NW wind occurs after a quiet period to take it as a 'reference' situation. This allows us to avoid the potential remnant effect of a previous wind event on the circulation. Hence, we have chosen to first concentrate on 2005 and show the simple case of the A1_2005 eddy (Figure 5). Following a quiet period with no wind, the wind starts blowing on June 30, 2005. It lasts until July 13 (with 
a) 20050713

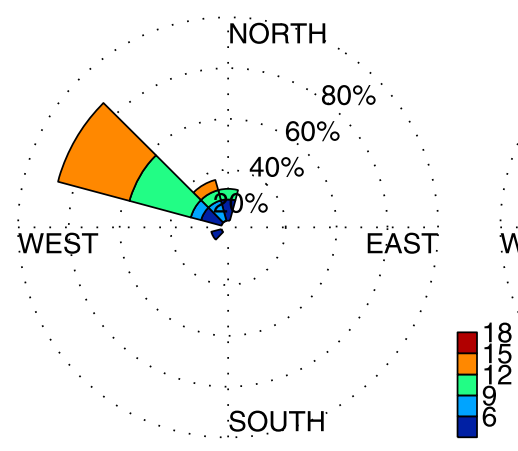

b) 20050718

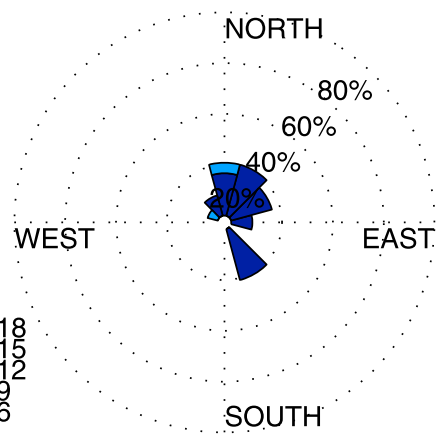

c) 20050821

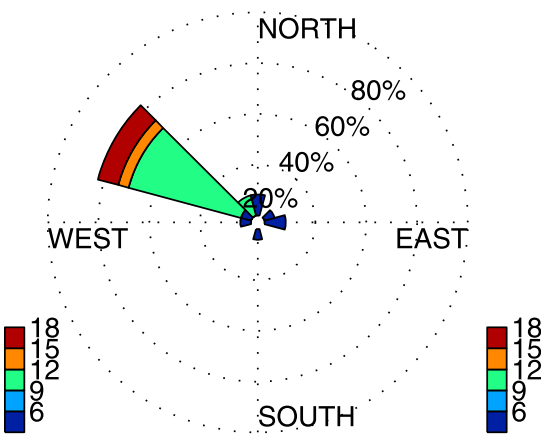

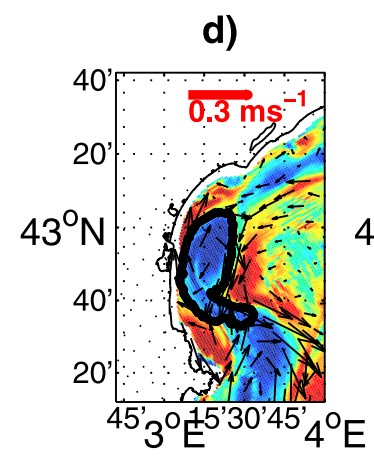

e)
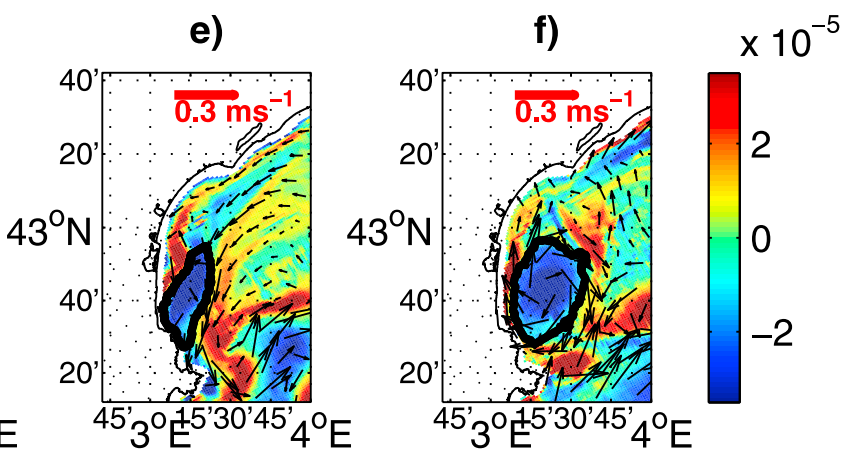

Figure 6. Time sequences of the evolution of the eddy A1_2005. Wind rose representation (intensity and frequency) at station Leucate on (a) $2005 / 07 / 11$ to 13 , (b) $2005 / 07 / 16$ to 18 , and (c) $2005 / 08 / 19$ to 21 , with the location and extension of the fan sector indicating of a wind direction and its percentage and colors representing wind intensity. Relative vorticity $\left(s^{-1}\right)$ computed at $20 \mathrm{~m}$ depth and current velocity fields corresponding to the same depth on (d) 2005/07/13, (e) 2005/07/18, and (f) 2005/08/21. Black contours show the eddy identification issued from the wavelet analysis.

one day of recession on July 4). It creates the long-life eddy A1_2005 observed from July 10 till September 4, hence lasting 57 days. Figure 5 illustrates different stages during the eddy's formation.

[29] As mentioned earlier, from June 26 to 28 , there is no strong wind in the western part of the GoL (Figure 5a). On June 28, the currents along the Roussillon coast are southward over the entire water column with a decrease in magnitude with depth (Figures 5e and 5i). Then, a strong northwesterly blows almost persistently from June 30 to July 2 through the whole shelf with a maximum wind intensity of $15 \mathrm{~ms}^{-1}$ (Figure $5 b$ ). Offshore, the surface water over the shelf near the north and north-east coast around the Cape d'Agde is advected south-southwestward in response to Ekman transport perpendicular to the wind direction (Figure 5f). The sea surface level close to the north coast is depressed in consequence. An onshore current is observed at deeper depth partially compensating for the upwelled waters (Figure 5j). The surface southwestward Ekman transport is reinforced and constrained by the inner edge of the NC surface layer. Reciprocally, the NC itself is accelerated by the wind-derived circulation and becomes an even stronger barrier preventing the outlet of the southwestward Ekman transport into the Catalan sea. The water piles close to Cape Creus and creates a high SSHA around the cape. The northwesterly is absent on July 4 (not shown) but rises again the day after. The same process repeats itself and the SSHA near the west coast increases. On July 6 , the north-south surface pressure gradient starts to create a northward current along the Roussillon coast (Figure 5k). This northward coastal current follows the curved shape of the Roussillon coast. It then turns to the open sea near the Cape d'Agde and joins the southwestward offshore current. This creates an anticyclonic structure while the surface current is still governed by the wind and keeps its southwestward onshore movement and keeps on accumulating near the southern coast. On July 10, the wavelet analysis detects the 'birth' of the eddy. The shape of this eddy, identified by the wavelet analysis at $20 \mathrm{~m}$ depth, corresponds well with the relative high SSHA at the surface associated with the eddy structure. The eddy is about 20 $30 \mathrm{~km}$ in diameter and extends through the mixed layer. The advected warm water from the shelf surface accumulated near the western coast is the water source for this anticyclonic eddy. The strong northwesterly persists for 9 days until July 13 . The eddy, fed continually under the same process by the coastal northward jet current, increases in size and intensity. At the end of this persisting northwesterly event, the eddy has an approximate north-south elliptical shape and is about $30-40 \mathrm{~km}$ in diameter (Figure 6d). The 'tail' at its southern edge reveals its interaction with the NC. Indeed, the eddy has moved southward with respect to the formation area. The eddy weakens when the supply process of wind-driven energy stops. From July 14 to 18, the northwesterly disappears for 5 days. By the end of this no wind period, the eddy size has reduced to almost half. The eddy has slightly moved southward to the coast (Figure 6e) following 
a) 2001

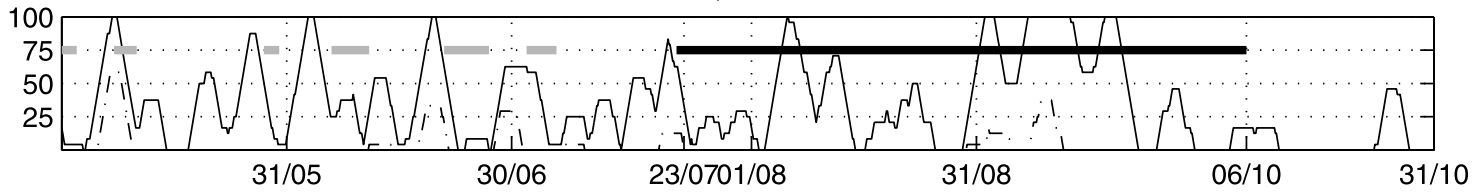

b) 2002

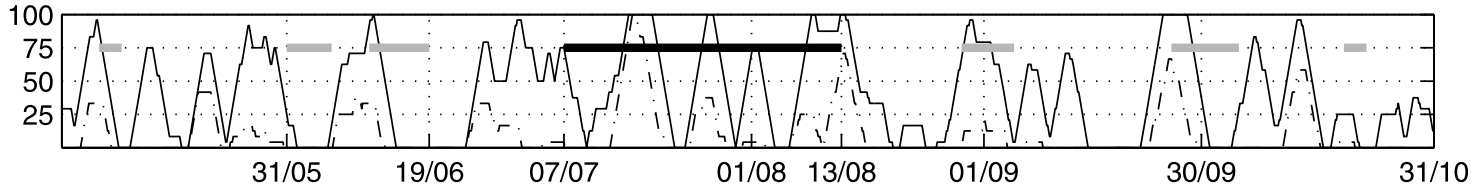

c) 2003

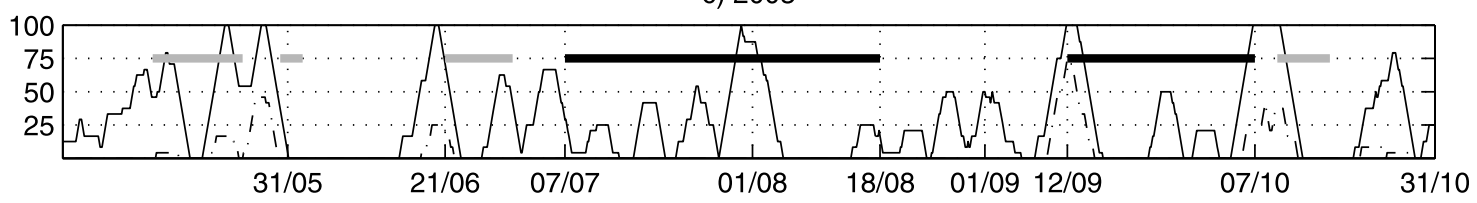

d) 2004
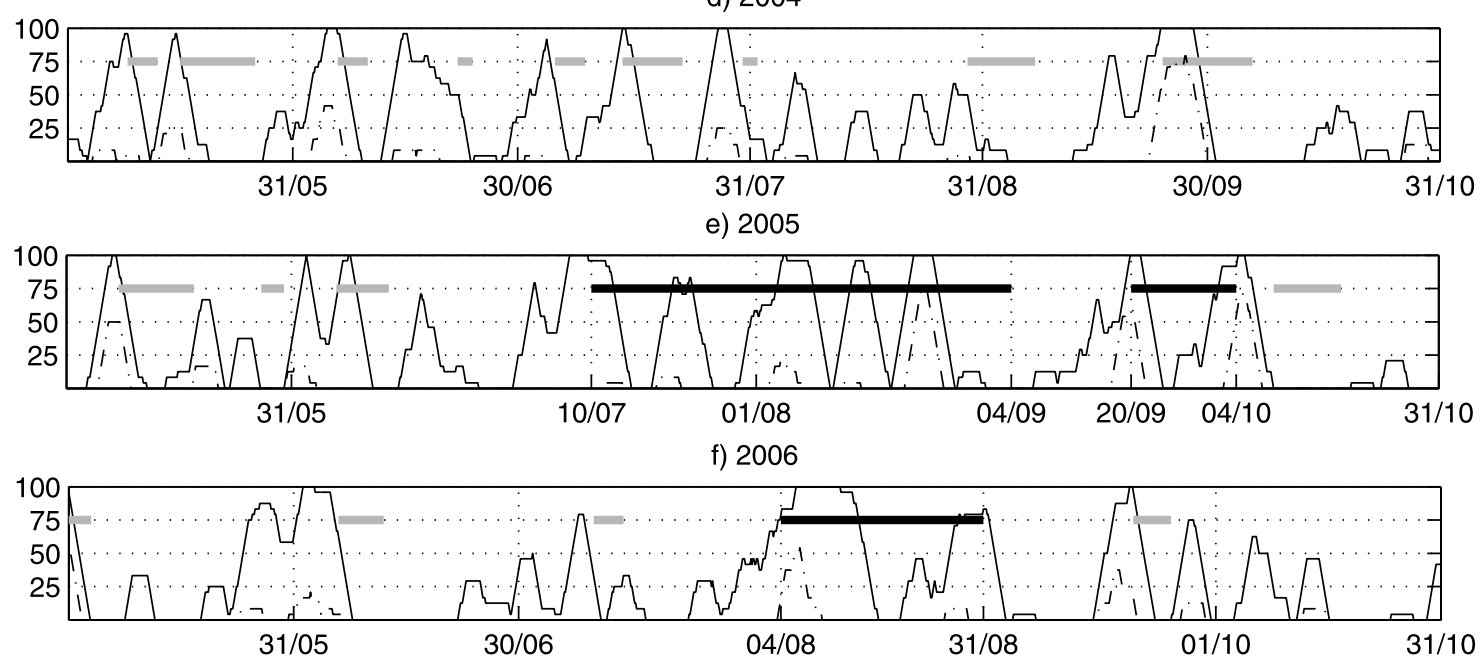

g) 2007

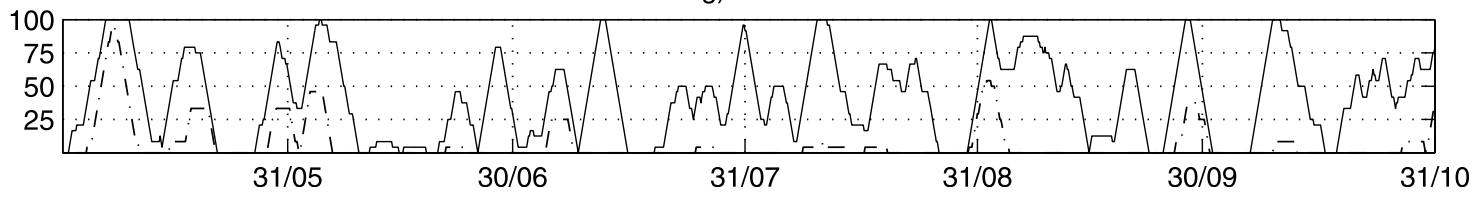

Figure 7. Temporal evolution of northwesterly expressed as a percentage of all wind, with a 3 day moving average, (solid line, northwesterly intensity $\geq 8 \mathrm{~ms}^{-1}$; dashed line, $\geq 14 \mathrm{~ms}^{-1}$ ) from May 1 to October 31 for each year. The presence of 'long-life' eddies is indicated by a horizontal black thick line and the 'short-life' eddies' presence is indicated by a gray thick line.

the relaxation of the surface pressure gradient. The eddy intensity has also decreased and its shape has become more elongated. Afterwards, several strong northwesterly events occur in succession with little gaps between them until August 20. At this time, the eddy has become a quite intense structure, less elongated and is about $50 \mathrm{~km}$ in diameter (Figure 6f).

[30] The same work has been performed on all the simulated anticyclonic structures in the western part of the GoL for the 8 years of simulations. It shows that the wind-driven generation mechanism of the eddy A1_2005 is valid for all other eddies, long-life eddies as well as short-life ones.
A systematic analysis is done calculating the percentage of strong northwesterly events, with two thresholds (one $\geq$ $8 \mathrm{~ms}^{-1}$ and the other one $\geq 14 \mathrm{~ms}^{-1}$ ), during the last three days at Leucate station from May 1 to October 31 for the 8 years of simulations (Figure 7). The presences of long-life anticyclonic eddies (black thick lines) and short-life anticyclonic features (gray thick lines) within this period reveal very clearly the correlation between persistent NW events and the eddies' generation. In general, a strong NW wind event persisting more than about $75 \%$ during 3 days referred to as a persistent strong NW wind - is a necessary condition to have an anticyclonic structure formed in the 


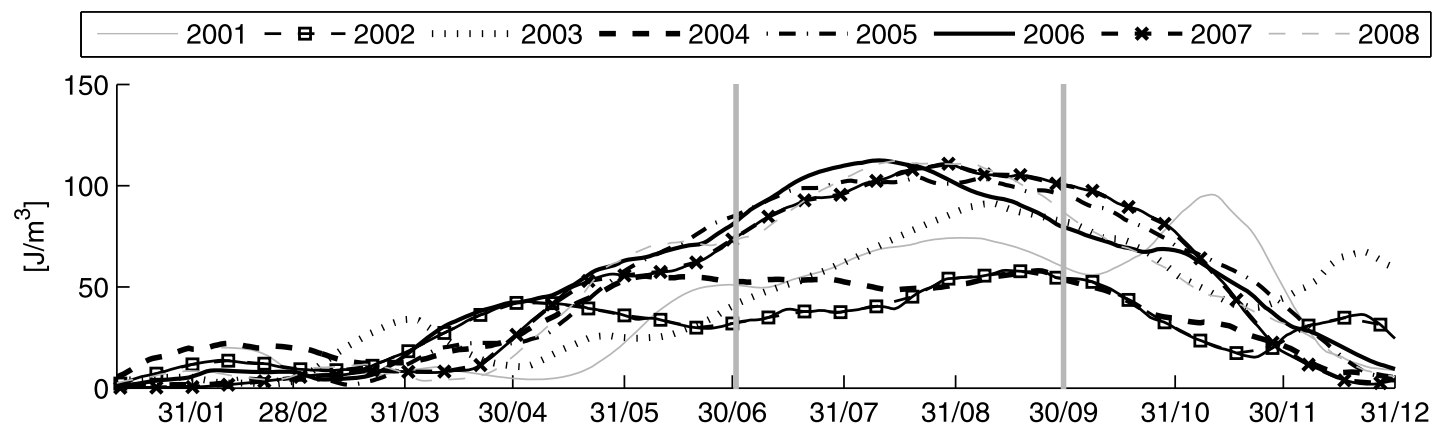

Figure 8. Time series of 30 day moving averaged absolute potential energy anomaly $\left[\mathrm{J} / \mathrm{m}^{3}\right]$ over the western part of the GoL for the upper $100 \mathrm{~m}$ depth for the years 2001-2008.

study zone. A sensitivity analysis has been done on the percentage of the northwesterly, varying the period from 1 to 5 days. The results show that the period of 3 days has the best correlation with the eddy's formation. If the percentage does not reach $75 \%$, but the wind persists for more than 3 days, the cumulative effects of the wind can also generate eddies like the two short-life eddies of early July 2001 (Figure 7a) and early May 2003, as well as the long-life eddy A1_2003 (Figure 7c). Moreover, a strong northwesterly is also necessary after the eddy's formation to sustain and to fuel the structure. For instance, in 2006, only one persistent northwesterly event occurs around July 7 and creates an eddy structure (Figure 7f). No more persistent northwesterly occurs after its formation. The size of this eddy stays in the range of sub-mesoscale; it disappears after existing only 5 days and hence is not classified as a 'long-life' eddy. While in early August, the northwesterly, persisting for more than half a month, creates the long-life eddy A1_2006.

\subsection{Influence of Stratification Conditions}

[31] Strong northwesterly events may arise at any time of the year in this area. However, coherent eddies occur only between May and October, while during the winter-spring season, no eddies can be formed even if a strong northwesterly event occurs.

[32] The high probability of observing a long-life anticyclonic eddy during the summer season suggests that the stratification condition probably plays a role on the eddy's generation dynamics. Hence, in the second phase, the influence of stratification condition on eddy generation is investigated.

[33] In order to study the annual variation of the stratification, the potential energy anomaly $\phi$ is chosen as the indication of the stability of the water column. This parameter is defined by Simpson [1981] and Simpson and Bowers [1981] as:

$$
\phi=\frac{1}{D} \int_{-H}^{\eta} g z(\bar{\rho}-\rho) d z
$$

with the depth-mean density $\bar{\rho}$ defined as:

$$
\bar{\rho}=\frac{1}{D} \int_{-H}^{\eta} \rho d z
$$

where $\rho$ is the density, $H$ the bathymetry, $\eta$ the sea surface elevation, $D=H+\eta$ the water column depth and $g$ the gravitational acceleration. For a given density profile, $\phi$ represents the amount of mechanical energy required to instantaneously homogenize the water column. This parameter has been used successfully as a criterion to study the phenomena concerning stratification [Burchard and Burchard, 2008; De Boer et al., 2008; Schaeffer, 2010]. The value of $\phi$ decreases with the level of homogeneity through the water column. Higher values of $\phi$ indicate a stronger stratification.

[34] During the winter-spring season, $\phi$ is minimum in magnitude with a value less than $20 \mathrm{Jm}^{-3}$, indicating a weak stratification (Figure 8). In general, the increase of $\phi$ in early May indicates the establishment of the seasonal stratification variation. $\phi$ reaches a maximum value late June, stays at this level about 3 months till late September and then diminishes with the fall/winter mixing. July, August and September are the months with the maximum value $\phi$ of about $100 \mathrm{Jm}^{-3}$. The most stratified conditions are observed during these months and coincidence with the occurrence of all the longlife eddies. We note that $\phi$ is relatively smaller in 2002 and 2004 compared with the value of $\phi$ of all the other years, with a value of about $60 \mathrm{Jm}^{-3}$ during July September.

[35] Hence, three stratified conditions can be defined by the range of the $\phi$ value: 1) a weak stratification with a value $\phi$ below $20 \mathrm{Jm}^{-3}$, as the one in winter-spring season; 2) an intermediate stratification with a value $\phi$ around $60 \mathrm{Jm}^{-3}$; as the one in early May and late October of all years and during the summer season in 2002 and 2004; 3) a strong stratification with a value $\phi$ reaching $100 \mathrm{Jm}^{-3}$, as during all summer seasons except 2002 and 2004. In 2004, no long-life eddy ever occurs despite the successive strong northwesterly events. We think that this is due to the too weak stratification of that summer. The year 2005 is used again to demonstrate the influence of stratification.

[36] A short-life eddy, referred to as A0_2005, is present in early May. Eddy A0_2005 is born on May 8 and disappears on May 18, lasting only 11 days. The strength and horizontal size of this short-life eddy are almost one third the ones of long-life eddy A1_2005 (Figure 9, left) that lasts 57 days from July 10 till September 4.

[37] The vertical extent of both anticyclonic eddies, clearly revealed by the areas with high magnitude of current intensity associated with the eddy rotation, is about $30-35 \mathrm{~m}$ (40$50 \mathrm{~m}$ ) for the eddy A0_2005 (A1_2005) (Figure 9, middle). Vertical transects of density show that both eddies are vertically constrained by the thermocline and hence have baroclinic characteristics (Figure 9, right). The deepening 
a) 20050512
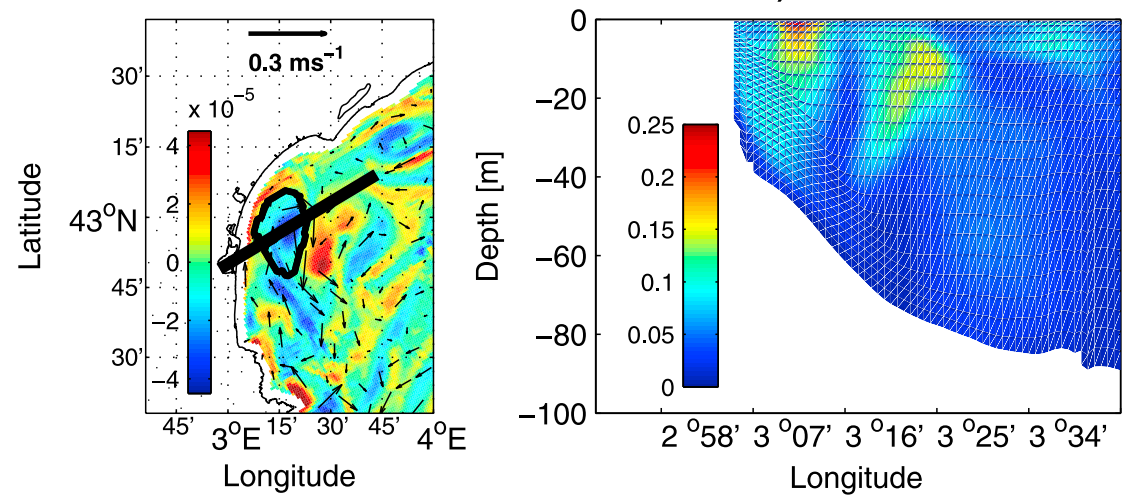

b) 20050819
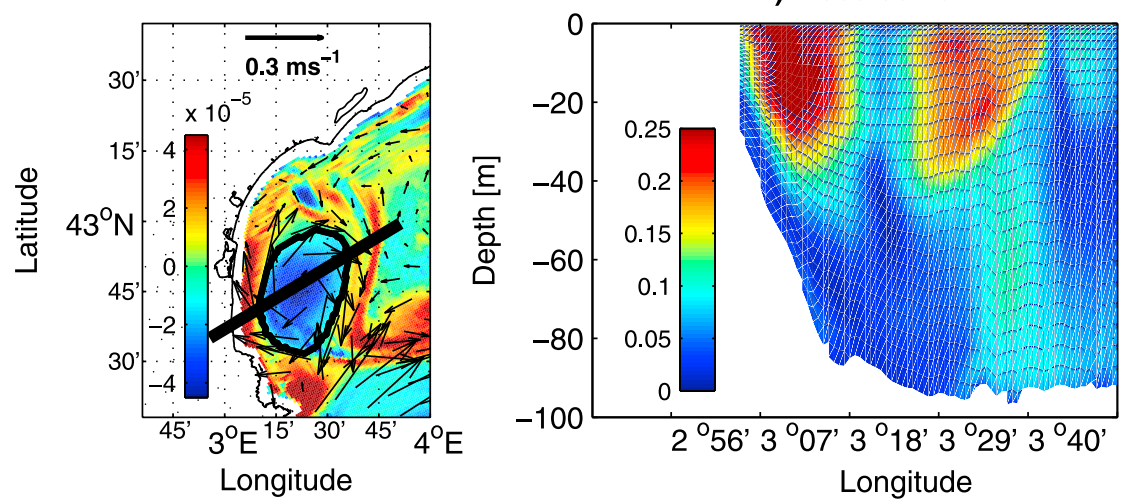
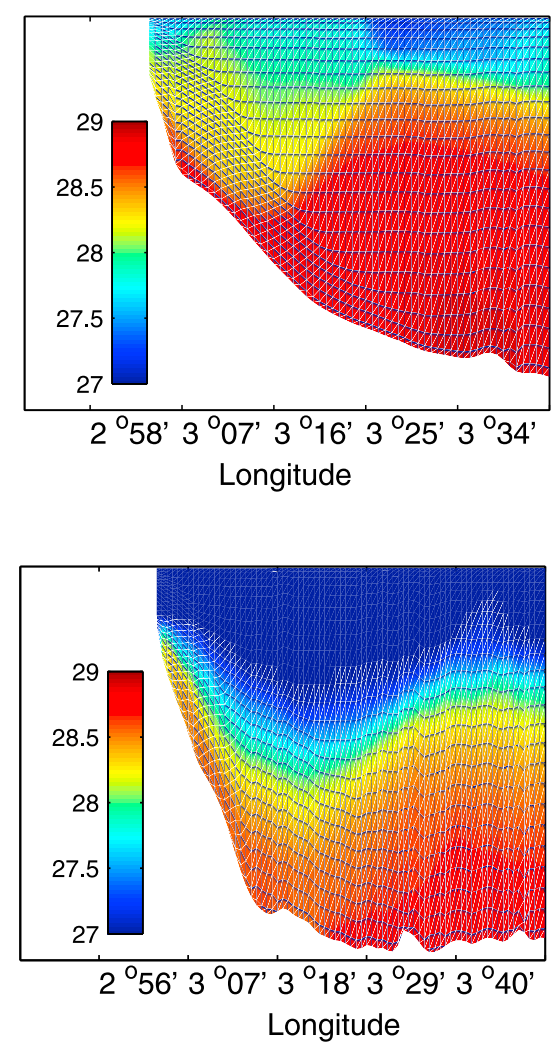

Figure 9. (left) Relative vorticity at $20 \mathrm{~m}$ depth, current velocity fields and eddy contour, where the black line marks the eddy cross-section; (middle) vertical transect of current intensity [ $\mathrm{ms}^{-1}$ ]; and (right) vertical transect of density for (a) May 12 and (b) August 19, in 2005.

of the pycnocline in both vertical sections is due to the eddy-induced downwelling within an anticyclonic structure. Excluding the eddy deepening effect, the mixing layer depth $(\sim 20 \mathrm{~m})$ in early May is shallower than the one in midAugust $(\sim 40 \mathrm{~m})$. The density gradient between the surface mixed layer and the deeper layer is also less in May than in August. Both differences indicate that the stratification in early May is weaker than in August, in accordance with the evolution of $\phi$. The long-life eddy A1_2005 is hence deeper in vertical extent and has more buoyant water within its core compared to the short-life eddy A0_2005.

[38] The differences of eddy characteristics between A0_2005 and A1_2005 can be observed between the other short-life and long-life eddies. Such differences, combined with the evolution of the density stratification, suggest that the eddy's size, vertical extent, strength and life duration increase with the stratification condition. During winterspring, the vertical water column is almost homogenous, and hence is not favorable to eddy generation. The July to September period exhibits the most stratified condition, and hence all the long-life eddies occur within this period. May, June and October have a stratification stronger than the winter-spring one, but smaller than the July September one. The structures occurring during these 3 months are therefore intermediate in nature, more stable than the filaments observed in winter-spring, but smaller, shallower and less intense than the long-life eddies of July to September. Hence, to have a long-life anticyclonic eddy in the western part of the GoL, the second necessary condition, in addition to strong northwesterly events, is a strong stratification.

\section{Discussion}

[39] As described by Crépon and Richez [1982] in their analytical study of coastal upwelling, symmetric offshore wind jets blowing perpendicular to the coast can generate offshore upwellings with extension of the order of the internal radius of deformation; anticyclonic (cyclonic) eddies may arise to the right (left) side of the wind axis (looking downwind) due to the spatial variation of wind stress and downward (upward) Ekman pumping associated. Based on their analytical solutions, Hua and Thomasset [1983] numerically studied the wind-induced upwelling in the GoL, and revealed that upwelling center can be located near the segment of the coastline from Leucate to Cape d'Agde. Anticyclonic eddies formed following an upwelling in this area are present on the right side of the Tramontane jet and have a size of the order of the Rossby radius of this area when they begin to be formed. Their size increases with time to about $80 \mathrm{~km}$ when they get fully developed. No cyclonic counterpart has been observed in the eastern part of the GoL like the symmetric vortex illustrated by Crépon and Richez [1982], this might be explained by the variability of the coastline. The cyclonic component of the NW Tramontane wind perpendicular to 
the north-east coast is very small due to the curvature of the coastline [Hua and Thomasset, 1983]. Similar situations have been described in the gulf of Tehuantepec in the eastern tropical Pacific Ocean, where mesoscale anticyclonic eddies are induced by strong, offshore winds [Trasvinã et al., 1995; Willett et al., 2006] in the western gulf. They are also present in the right side (since it is in the Northern hemisphere) of the axis of the wind and are several times the Rossby radius. The flow pattern in the gulf of Tehuantepec also shows an asymmetric feature with no corresponding cyclone present in the eastern gulf. Trasvinã et al. [1995] showed that, in their case, the entrainment associated with wind stirring is responsible for the weakening of the cyclonic eddies and that the uplifted thermocline, which maintains the cyclonic eddy, is weakened by the mixing process. The analytical study by Crépon and Richez [1982] also showed that the upwelling is linked to the motion of the interface generated by the baroclinic mode and is dependant on the stratification. This can be linked to the important role of the stratification condition on the generation of eddies following the upwelling phenomenon in this area. If we consider the energy cycle as presented by Böning and Budich [1992], the injection of energy by the northwesterly wind can be transferred into potential energy $(\mathrm{PE})$ when the wind-driven Ekman transport pushes the buoyant surface water to the west coast near Cape Creus and then downward there. The eddy generation is driven primarily through the release of PE by baroclinic process [Holland and Haidvogel, 1980; Ferrari and Wunsch, 2009]. The mean field PE can also be converted into eddy PE by baroclinic process [Böning and Budich, 1992]. In our case, strong wind events would be the source of energy, and a well-stratified condition would favor the transfer.

[40] The combined effects of both factors, the wind-forcing and the stratification, at different levels, and their respective influence on eddy's formation, are discussed in the following six cases:

[41] i) we think that if no persistent NW wind events is present, whether stratification is strong or not, no eddy formation could occur. No such case are present in the simulations to confirm our hypothesis since there are always NW wind events in the region.

[42] ii) Instead, when a persistent strong northwesterly event occurs while stratification is weak, anticyclonic filaments are generated like the ones formed during winter-spring.

[43] iii) When a persistent strong northwesterly event occurs with an intermediate stratification, eddy structures can arise but they possess a short-life duration, small size, shallow depth and weak intensity. They correspond to the short-life eddies formed in May, June and late October. In 2004 (as in 2002), stratification during July September is not as strong as during the other years and is referred to as 'intermediate' (Figure 8). Several persistent strong NW wind events occur in July 2004, creating transient eddies; but no long-life structures occurs in 2004 (Figure 7d).

[44] iv) When extremely strong persistent northwesterly events occur, long-life eddies can exist despite the intermediate stratification. The long-life eddy A1_2002 is generated in this situation. The stratification during summer 2002 being intermediate implies that summer 2002 should not be favorable to long-life eddies. Nevertheless, in 2002, the NW wind has the maximum average intensity $\left(20 \mathrm{~ms}^{-3}\right)$ over the 8 years (Table 1). Moreover its percentage of $59 \%$ is the second highest one after 2007. In fact the strong wind bursts are also especially concentrated from July to August (Figure 7b). Despite the stratification, but thanks to the strong energy injection, the long-life anticyclonic eddy A1_2002 is formed but with a size smaller than the ones of the other long-life ones (Figure 4).

[45] v) When persistent strong northwesterly events and a strong stratification coexist, intense, long-life eddy can be generated. The other 7 long-life eddies: A1_2001, A1_2002, A1_2003, A2_2003, A1_2005, A2_2005 and A1_2008 are generated in this case.

[46] In 2006, the long-life eddy lasts only 22 days. 2006 is the year with the least presence of long-life eddy (Table 2). This can be explained by the fact that 2006 has the minimum percentage of the northwesterly (47\%) of all years during this 8 -year period (Table 1). Moreover, the wind has a weak intensity, comparable with the one in 2004. However, the strong stratification in 2006 compensates for the weak windforcing hence the long-life eddy A1_2006 exists but with a shorter duration.

[47] vi) When extremely strong persistent northwesterly events occur with a strong stratification, the anticyclonic eddy increases in scale and becomes an anticyclonic circulation like the one observed in 2007 (Figure 4h). Indeed, on one hand, the stratified condition in 2007 present from late June till late October, is quite strong as shown in Figure 8. On the other hand, the northwesterly in 2007 has the largest percentage $(62 \%)$ of all years and its intensity is the seconder highest (Table 1). Both conditions for eddy formation are more than satisfied; hence such anticyclonic circulation can be considered as an extreme case of an eddy-like structure.

\section{Summary and Conclusion}

[48] A realistic numerical model has been used in the present work to study the generation of mesoscale anticyclonic eddies located in the western part of the GoL between January 2001 and December 2008. Eddy's life duration varies from several days to several months. During the 8 years of simulation, 8 long-life anticyclonic eddies with a life duration longer than 15 days have been detected. They all occur between July and early October. Compared with the short-life structures occurring in May, June and late October, the long-life eddies have a bigger size, a deeper vertical extension and are more intense.

[49] Indeed, the simulated long-life eddies have dimensions, at the beginning of their life, of the same order of the Rossby radius of this area. Their size increases with time and becomes several times the Rossby radius when they get fully developed.

[50] The simulated eddies are baroclinic, as the in situ anticyclonic eddy observed in early September 2008 in the study area during the Latex 08 cruise [Hu et al., 2011].

[51] The formation process can be described schematically by Figure 10. A strong northwesterly persisting at least $75 \%$ of the previous 3 days induces an Ekman transport piling the water close to Cape Creus (Figure 10a). A northward current along the Roussillon coast is created (Figure 10b). This current turns to its right approaching Cape d'Agde and generates an anticyclonic circulation (Figure 10c) that is the precursor 
a)

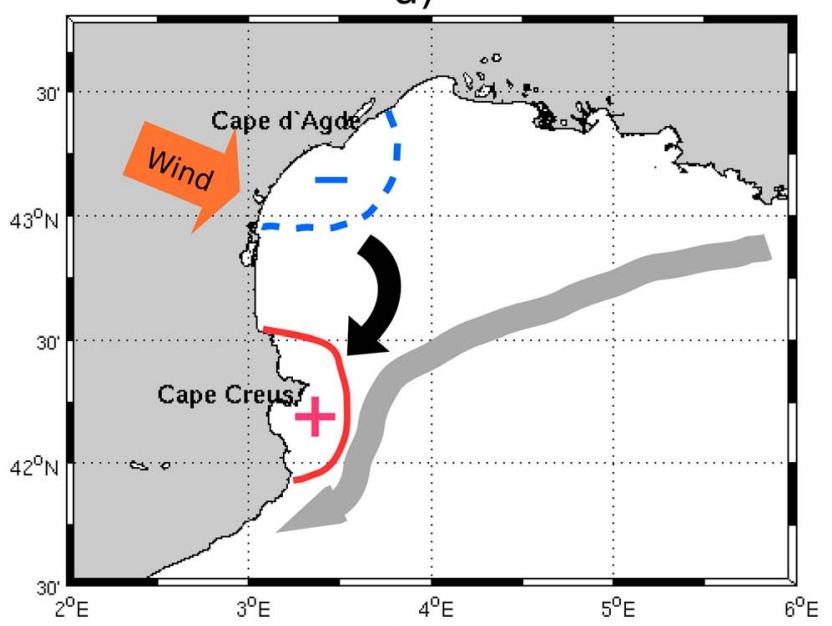

b)

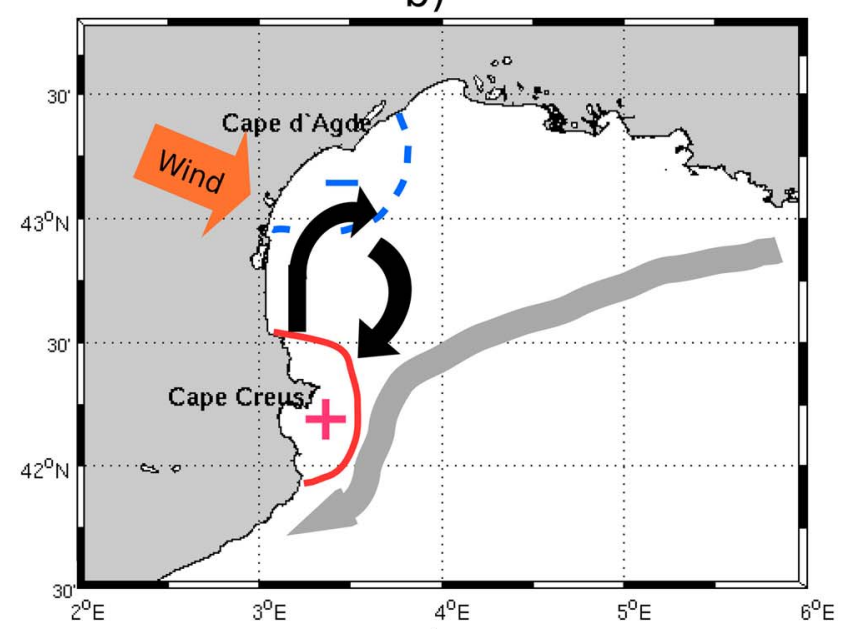

C)

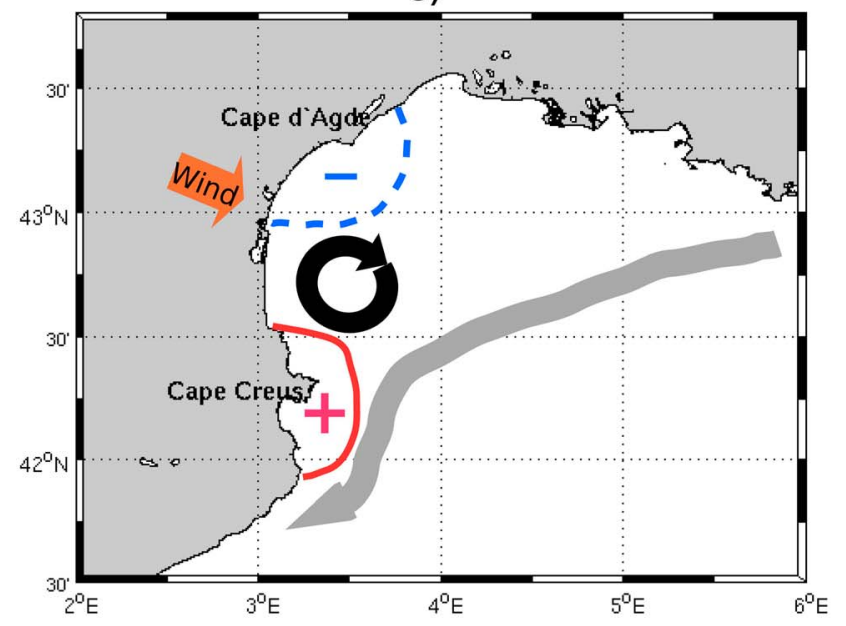

Figure 10. Schematic of anticyclonic eddy generation process. Wind-forcing is indicated by the orange arrows; also shown are sea surface level (red plus or blue minus zones), surface currents (black thick arrow), and NC (gray thick line). of an anticyclonic eddy. After this initial generation phase, the results show that persistent strong northwesterly and a strong stratification guarantee the generation of a long-life eddy in the western part of the GoL. Different cases can be found varying the combination of these two conditions, hence leading to situations from short-life eddies to extended anticyclonic circulation.

[52] Hence, this work explains in details the generation mechanism of the eddy, first observed by Millot [1979, 1982]. Moreover, it could be used to improve the short-term numerical predictability of the complex coastal circulation in the study area.

[53] Acknowledgments. The LATEX projet is supported by the programs LEFE/IDAO and LEFE/CYBER of the INSU-Institut National des Sciences de l'Univers and by the Region PACA-Provence Alpes Côte d'Azur. We thank Météo-France for providing the meteorological data at coastal stations around the Gulf of Lion and the meteorological forcing obtained from the ALADIN model. We acknowledge the GNOO-INGV for providing initial and open boundary conditions obtained from the MFS model. Z.Y. Hu is financed by a MENRT Ph.D. grant.

\section{References}

Albérola, C., and C. Millot (2003), Circulation in the French Mediterranean coastal zone near Marseilles: The influence of the wind and the Northern Current, Cont. Shelf Res., 23, 587-610.

Albérola, C., C. Millot, and J. Font (1995), On the seasonal and mesoscale variabilities of the Northern Current during the PRIMO-0 experiment in the western Mediterranean Sea, Oceanol. Acta, 18, 163-192.

Allou, A., P. Forget, and J. Devenon (2010), Submesoscale vortex structures at the entrance of the Gulf of Lions in the northwestern Mediterranean Sea, Cont. Shelf Res., 30(7), 724-732, doi:10.1016/j.csr.2010.01. 006.

Arakawa, A., and M. Suarez (1982), Vertical differencing of the primitive equations in sigma coordinates, Mon. Weather Rev., 111, 34-45, doi:10.1175/1520-0493(1983)111.

Auclair, F., P. Marsaleix, and P. De Mey (2003), Space-time structure and dynamics of the forecast error in a coastal circulation model of the Gulf of Lions, Dyn. Atmos. Oceans, 36, 309-346, doi:10.1016/S0377-0265 (02)00068-4.

Böning, C. W., and R. G. Budich (1992), Eddy dynamics in a primitive equation model: Sensitivity to horizontal resolution and friction, J. Phys. Oceanogr., 22, 361-381.

Burchard, H., and R. Burchard (2008), A dynamic equation for the potential energy anomaly for analysing mixing and stratification in estuaries and coastal seas, Estuarine Coastal Shelf Sci., 77(4), 679-687, doi:10.1016/ j.ecss.2007.10.025

Chavanne, C., P. Flament, R. Lumpkin, B. Dousset, and A. Bentamy (2002), Scatterometer observations of wind variations induced by oceanic islands: Implications for wind-driven ocean circulation, Can. J. Remote Sens., 28(3), 466-474.

Crépon, M., and C. Richez (1982), Transient upwelling generated by 2-D atmospheric forcing and variability in the coastline, J. Phys. Oceanogr., 12, 1437-1457.

De Boer, G. J., J. D. Pietrzak, and J. C. Winterwerp (2008), Using the potential energy anomaly equation to investigate tidal straining and advection of stratification in a region of freshwater influence, Ocean Modell., 22, 1-11.

Dencausse, G. J., M. Arhan, and S. Speich (2010), Routes of Agulhas rings in the southeastern Cape Basin, Deep Sea Res., Part I, 57, 1406-1421, doi:10.1016/j.dsr.2010.07.008.

Doglioli, A., A. Griffa, and M. Magaldi (2004), Numerical study of a coastal current on a steep slope in presence of a cape: The case of the Promontorio di Portofino, J. Geophys. Res., 109, C12033, doi:10.1029/ 2004JC002422

Doglioli, A. M., B. Blanke, S. Speich, and G. Lapeyre (2007), Tracking coherent structures in a regional ocean model with wavelet analysis: Application to Cape Basin Eddies, J. Geophys. Res., 112, C05043, doi:10.1029/2006JC003952.

Dufau-Julliand, C., P. Marsaleix, A. Petrenko, and I. Dekeyser (2004), Three-dimensional modeling of the Gulf of Lion's hydrodynamics (northwest Mediterranean) during January 1999 (MOOGLI3 Experiment) and late winter 1999: Western Mediterranean Intermediate Water's (WIW's) formation and its cascading over the shelf break, J. Geophys. Res., 109, C11002, doi:10.1029/2003JC002019. 
Echevin, V., M. Crepon, and L. Mortier (2003), Interaction of a coastal current with a gulf: Application to the shelf circulation of the Gulf of Lions in the Mediterranean Sea, J. Phys. Oceanogr., 33, 188-206.

Estournel, C., V. Kondrachoff, P. Marsaleix, and R. Vehil (1997), The plume of the Rhône: Numerical simulation and remote sensing, Cont. Shelf Res., 17(8), 899-924, doi:10.1016/S0278-4343(96)00064-7.

Estournel, C., X. Durrieu de Madron, P. Marsaleix, F. Auclair, C. Julliand, and R. Vehil (2003), Observation and modeling of the winter coastal oceanic circulation in the Gulf of Lion under wind conditions influenced by the continental orography (FETCH experiment), J. Geophys. Res., 108(C3), 8059, doi:10.1029/2001JC000825.

Ferrari, R., and C. Wunsch (2009), Ocean circulation kinetic energy: Reservoirs, sources, and sinks, Annu. Rev. Fluid Mech., 41, 253-282, doi:10.1146/annurev.fluid.40.111406.102139.

Flexas, M. M., X. Durrieu de Madron, M. A. Garcia, M. Canals, and P. Arnau (2002), Flow variability in the Gulf of Lions during the MATER HFF experiment (March-May 1997), J. Mar. Syst., 33-34, 197-214, doi:10.1016/S0924-7963(02)00059-3.

Gaspar, P., Y. Grégoris, and J.-M. Lefevre (1990), A simple eddy kinetic energy model for simulations of the oceanic vertical mixing: Tests at Station Papa and long-term upper ocean study site, J. Geophys. Res., 95, 179-193.

Grilli, F., and N. Pinardi (1998), The computation of Rossby radii dynamical processes of deformation for the Mediterranean Sea, MTP News, 6, 4

Herrmann, M. J., and S. Somot (2008), Relevance of ERA40 dynamical downscaling for modeling deep convection in the Mediterranean Sea, Geophys. Res. Lett., 35, L04607, doi:10.1029/2007GL032442.

Herrmann, M., S. Somot, F. Sevault, C. Estournel, and M. Déqué (2008), Modeling the deep convection in the northwestern Mediterranean Sea using an eddy-permitting and an eddy-resolving model: Case study of winter 1986-1987, J. Geophys. Res., 113, C04011, doi:10.1029/2006JC003991.

Holland, W. R., and D. B. Haidvogel (1980), A parameter study of the mixed instability of idealized ocean currents, Dyn. Atmos. Oceans, 4(3), 185-215, doi:10.1016/0377-0265(80)90014-7.

Hu, Z. Y., A. A. Doglioli, A. M. Petrenko, P. Marsaleix, and I. Dekeyser (2009), Numerical simulations of eddies in the Gulf of Lion, Ocean Modell., 28(4), 203-208, doi:10.1016/j.ocemod.2009.02.004.

Hu, Z. Y., A. A. Petrenko, A. M. Doglioli, and I. Dekeyser (2011), Study of coastal eddies: Application in the Gulf of Lion, J. Mar. Syst., 88, 3-11, doi:10.1016/j.jmarsys.2011.02.008.

Hua, B., and F. Thomasset (1983), A numerical study of the effects of coastline geometry on wind-induced upwelling in the Gulf of Lions, J. Phys. Oceanogr., 13, 678-694.

Hurlburt, H. E., and J. D. Thompson (1980), A numerical study of Loop Current intrusions and eddy shedding in Gulf of Mexico, J. Phys. Oceanogr., 10, 1611-1631.

Huthnance, J. M. (1995), Circulation, exchange and water masses at the ocean margin: The role of physical processes at the shelf edge, Prog. Oceanogr., 35(4), 353-431, doi:10.1016/0079-6611(95)80003-C.

Kersalé, M., A. M. Doglioli, and A. A. Petrenko (2011), Sensitivity study of the generation of mesoscale eddies in a numerical model of Hawail Islands, Ocean Sci., 7, 277-291, doi:10.5194/os-7-277-2011.

Ludwig, W., E. Dumont, M. Meybeck, and S. Heussner (2009), River discharges of water and nutrients to the Mediterranean and Black Sea: Majo drivers for ecosystem changes during past and future decades?, Prog. Oceanogr., 80(3-4), 199-217, doi:10.1016/j.pocean.2009.02.001.

Lumpkin, C. F. (1998), Eddies and currents in the Hawaii islands, Ph.D. thesis, Univ. of Hawai'i at Mānoa, Honolulu.

Magaldi, M., T. Özgökmen, A. Griffa, and M. Rixen (2010), On the response of a turbulent coastal buoyant current to wind events: The case of the Western Adriatic Current, Ocean Dyn., 60, 93-122, doi:10.1007/ s10236-009-0247-9.

Marsaleix, P., F. Auclair, and C. Estournel (2006), Considerations on open boundary conditions for regional and coastal ocean models, J. Atmos. Oceanic Technol., 23, 1604-1613, doi:10.1175/JTECH1930.1.

Marsaleix, P., F. Auclair, J. Floor, M. Herrmann, C. Estournel, I. Pairaud, and C. Ulses (2008), Energy conservation issues in sigma-coordinate free-surface ocean models, Ocean Modell., 20, 61-89, doi:10.1016/j. ocemod.2007.07.005

McWilliams, J. C. (1985), Submesoscale, coherent vortices in the ocean, Rev. Geophys., 23(2), 165-182, doi:10.1029/RG023i002p00165.

Millot, C. (1979), Wind induced upwellings in the Gulf of Lions, Oceanol. Acta, 2, 261-274.

Millot, C. (1982), Analysis of upwelling in the Gulf of Lions, in Hydrodynamics of Semi-enclosed Seas, Elsevier Oceanogr. Ser., vol. 34, edited by J. C. J. Nihoul, pp. 143-153, Elsevier, Amsterdam.

Millot, C. (1990), The Gulf of Lions' hydrodynamics, Cont. Shelf Res., 10, 885-894, doi:10.1016/0278-4343(90)90065-T.
Millot, C. (1991), Mesoscale and seasonal variabilities of the circulation in the western Mediterranean, Dyn. Atmos. Oceans, 15, 179-214 doi:10.1016/0377-0265(91)90020-G

Millot, C. (1999), Circulation in the Western Mediterranean Sea, J. Mar. Syst., 20, 423-442, doi:10.1016/S0924-7963(98)00078-5.

Millot, C., I. Taupier-Letage, and M. Benzohra (1990), The Algerian eddies, Earth Sci. Rev., 27, 203-219, doi:10.1016/0012-8252(90) 90003-E.

Minas, M., and H. Minas (1989), Primary production in the Gulf of Lions with considerations to the Rhône River input, Water Pollut. Res. Rep., 32(5), 112-125.

Pascual, A., B. Buongiorno Nardelli, G. Larnicol, M. Emelianov, and D. Gomis (2002), A case of an intense anticyclonic eddy in the Balearic Sea (western Mediterranean), J. Geophys. Res., 107(C11), 3183, doi:10.1029/2001JC000913.

Petrenko, A. A. (2003), Variability of circulation features in the Gulf of Lion NW Mediterranean Sea. Importance of inertial currents, Oceanol. Acta, 26, 323-338.

Petrenko, A. A., Y. Leredde, and P. Marsaleix (2005), Circulation in a stratified and wind-forced Gulf of Lions, NW Mediterranean Sea: In situ and modeling data, Cont. Shelf Res., 25, 7-27, doi:10.1016/j.csr.2004.09.004.

Petrenko, A. A., C. Dufau, and C. Estournel (2008), Barotropic eastward currents in the western Gulf of Lion, northwestern Mediterranean Sea, during stratified conditions, J. Mar. Syst., 74(1-2), 406-428, doi:10.1016/j.jmarsys.2008.03.004.

Pichevin, T., and D. Nof (1996), The eddy cannon, Deep Sea Res., Part I, 43(9), 1475-1507, doi:10.1016/S0967-0637(96)00064-7.

Pinardi, N., et al. (2003), The Mediterranean ocean forecasting system: First phase of implementation (1998-2001), Ann. Geophys., 21, 3-20.

Robinson, A. R., M. A. Spall, and N. Pinardi (1988), Gulf Stream simulations and the dynamics of ring and meander processes, J. Phys. Oceanogr., 18, 1811-1853.

Rubio,A., P. Arnau, M. Espino, M. Flexas, G. Jordà, J. Salat, J. Puigdefàbregas, and A. S.-Arcilla (2005), A field study of the behaviour of an anticyclonic eddy on the Catalan continental shelf (NW Mediterranean), Prog. Oceanogr., 66(2-4), 142-156, doi:10.1016/j.pocean. 2004.07.012.

Rubio, A., B. Barnier, G. Jordà, M. Espino, and P. Marsaleix (2009a) Origin and dynamics of mesoscale eddies in the Catalan Sea (NW Mediterranean): Insight from a numerical model study, J. Geophys. Res., 114, C06009, doi:10.1029/2007JC004245.

Rubio, A., B. Blanke, S. Speich, N. Grima, and C. Roy (2009b), Mesoscale eddy activity in the southern Benguela upwelling system from satellite altimetry and model data, Prog. Oceanogr., 83, 288-295.

Ruiz, S., J. Font, M. Emelianov, J. Isern-Fontanet, C. Millot, J. Salas, and I. Taupier-Letage (2002), Deep structure of an open sea eddy in the Algerian Basin, J. Mar. Syst., 33-34, 179-195, doi:10.1016/S09247963(02)00058-1.

Sammari, C., C. Millot, and L. Prieur (1995), Aspects of the seasonal and mesoscale variabilities of the Northern Current inferred from the PROLIG-2 and PROS-6 experiments, Deep Sea Res., Part I, 42, 893-917.

Schaeffer, J. (2010), Impact du vent sur la circulation hydrodynamique dans le Golfe du Lion: Modélisation haute résolution, Ph.D. thesis, Univ. du Sud Toulon-Var, La Garde, France.

Signell, R., and W. Geyer (1991), Transient eddy formation around headlands, J. Geophys. Res., 96(C2), 2561-2575.

Simpson, J. (1981), The shelf-sea fronts: Implications of their existence and behaviour, Philos. Trans. R. Soc. London, Ser. A, 302(1472), 531-546.

Simpson, J., and D. Bowers (1981), Models of stratification and frontal movement in shelf seas, Deep Sea Res., Part I, 28(7), 727-738, doi:10.1016/0198-0149(81)90132-1.

Thomas, L. N., A. Tandon, and A. Mahadevan (2008), Submesoscale processes and dynamics, in Ocean Modeling in an Eddying Regime, Geophys. Monogr. Ser., vol. 177, edited by M. W. Hecht and H. Hasumi, pp. 17-38, AGU, Washington, D. C

Trasvinã, A., E. D. Barton, J. Brown, H. S. Velez, P. M. Kosro, and R. L. Smith (1995), Offshore wind forcing in the Gulf of Tehuantepec, Mexico: The asymmetric circulation, J. Geophys. Res., 100(20), 649-663, doi:10.1029/95JC01283.

Ulses, C., C. Estournel, J. Bonnin, X. Durrieu de Madron, and P. Marsaleix (2008a), Impact of storms and dense water cascading on shelf-slope exchanges in the Gulf of Lion (NW Mediterranean), J. Geophys. Res., 113, C02010, doi:10.1029/2006JC003795.

Ulses, C., C. Estournel, P. Puig, X. Durrieu de Madron, and P. Marsaleix (2008b), Dense shelf water cascading in the northwestern Mediterranean during the cold winter 2005: Quantification of the export through the Gulf of Lion and the Catalan margin, Geophys. Res. Lett., 35, L07610, doi:10.1029/2008GL033257. 
Willett, C. S., R. R. Leben, and M. F. Lavín (2006), Eddies and tropical instability waves in the eastern tropical Pacific: A review, Prog. Oceanogr., 69, 218-238, doi:10.1016/j.pocean.2006.03.010.

I. Dekeyser, A. M. Doglioli, and A. A. Petrenko, Laboratoire d'Océanographie Physique et Biogéochimique, UMR6535, Aix-Marseille
Université, CNRS, IRD, OSU/Centre d'Océanologie de Marseille, Campus de Luminy, case 901, F-13288 Marseille CEDEX 9, France.

Z. Y. Hu, JiaoZhou Bay Marine Ecosystem Research Station, Institute of Oceanology, Chinese Academy of Sciences, 7 Nanhai Rd., 266071 Qingdao, China. (ziyuanhu@qdio.ac.cn) 